\title{
FORCED LABOUR IN BRAZIL: INTERNATIONAL CRIMINAL LAW AS THE ULTIMA RATIO MODALITY OF HUMAN RIGHTS PROTECTION
}

James L. Bischoff

Introduction: The contours of Contemporary Forced Labour in Brazil; 1. The international legal regime governing slavery and related activities; 1.1. Slavery, the slave trade, slavery-like practices, and forced labour as internationally wrongful acts entailing state responsibility; 1.2 . Slavery, the slave trade, slavery-like practices, and forced labour as international crimes entailing individual criminal responsibility; 2 . The modest achievements of Brazil's anti-forced-labour campaign; 2.1. Brazilian government action against forced labour; 2.2. Some reasons behind the government's lacklustre accomplishments; 3 . The international legal consequences of the continued existence of forced labour in Brazil; 3.1. The Brazilian state's responsibility for forced labour; 3.2. Individual international criminal responsibility for Brazilian forced labour; Conclusion: International criminal law as the ultima ratio modality of human rights protection

\begin{abstract}
Notwithstanding estimates that 12.3 million persons today are subjected to conditions analogous to slavery, public international lawyers have almost completely ignored slavery and related institutions in recent decades. This article explores the phenomenon of forced labour in the Amazon, where anywhere between 25,000 and 100,000 people are compelled through trickery and coercion to work in subhuman conditions. After outlining the legal regime governing slaveryrelated practices, the author examines why the Brazilian government has failed in its efforts to secure compliance within its own borders of its obligations under antislavery and human rights conventions. The author then argues that holding the Brazilian state responsible and assessing monetary damages is not in fact the most effective and fair way to secure the human rights of the victims of forced labour, and that international criminal sanctions for the individual perpetrators-including prosecution in the ICC for crimes against humanity -is a viable and preferable alternative.

* Associate Legal Officer, International Criminal Tribunal for the former Yugoslavia; LL.M. in Public International Law with international Criminal Law Specialisation (Leiden) 2005; J.D. (Texas) 2004; M.A. in Latin American Siudies (Texas) 2004. The views expressed herein are those of the author alone and do not necessarily reflect the views of the Intemational Criminal Tribunal for the fomer Yugoslavia or the United Nations in general. The author wishes to thank Professors John Dugard, Kunt Weyland, Steven Ratner, and Claudia Lima Marques, along with Dr. Rachel Cunha of the Brazilian Human Rights Secretariat, for their guidance in the preparation of this article.
\end{abstract}


Key Words: slavery; forced labour/labor; enslavement; Brazil; crimes against humanity; international criminal law; human rights; state responsibility

\section{Introduction: The contours of Contemporary Forced Labour in Brazil}

'[1]n various parts of Latin America, modernity is a fine veneer under which the old reality hides.' - Sérgio Paulo Moreyra, Brazilian historian'

In 1888 Brazil became the last country in the Americas to formally abolish chattel slavery; with the overthrow of the monarchy the following year, the new republic seemed poised to take its long overdue entry into the modern world. Yet a cursory glance at modern day Brazil reveals that many areas of society have not progressed much beyond 1889 . The re emergence of semi slavery in various parts of the country some four decades ago-assuming that such practices had ever actually ceased to exist in the first place-served to reinforce the notion that Brazil has not yet figured out how to fully extricate itself from the nineteenth century.

A sizable majority of Brazilian forced labour (an estimated 72 percent $^{2}$ ) occurs along the southern arc of the Amazon basin, in a vast and desolate region encompassing portions of the states of Pará, Mato Grosso, Maranhão, Goiás, Acre, Mato Grosso do Sul, and Tocantins. ${ }^{3}$ The military government in the 1960 s and 1970 s financed massive projects to open up the northern wilderness to take advantage of previously untapped economic potential and preclude incursions by would be foreign investors. ${ }^{4}$ Four of these Amazonian 'development' activities in particular have made heavy use of forced labour: forest clearing (including logging), cattle ranching and crop agriculture on cleared land, and charcoal production."

Wealthy regional landowners (fazendeiros) provide the funding for and outline the objectives of the operations on their holdings (fazendas). These fazendeiros typically own several fazendas and engage in many business ventures simultaneously, and thus pay little attention to what goes on at any one fazenda. The fazendeiro delegates management authority to subcontractors (empreiteiros), who in turn hire their own subcontractors (known as gatos, or

SP. Moreyra, 'Introduçāo', in Comissão Pastoral da Terra (ed.), Trabalho escravo no Brasil contemporâneo (1999), 11 at 12 (author's translation).

2 R. Brasiliense, 'Pelourinhos na floresta', Amazon Press, 2 December 2003, at http:// www.amazonpress.com.br/manchete/dedoc/manch02122003a.htm (quoting figures compiled by Brazilian sociologist losé de Souza Martins).

3 B. Le Breton, Vidas roubadas: A escravidão moderna na Amazônia brasileira (2002), 228.

* See generally ibid., at 55-70.

5 US Deparment of State, Country Reports on Human Rights Practices 2001: Brazil (2002), available at http://www.state.gov/g/drl/rls/hrrpt/2001/wha/8305.intm. See also International Labour Organization, Stopping Forced Labour: Global Report Under the Follow up to the lLO Declaration on Fundamental Principles and Rights at Work (2001), para. 67. Forced labour has also been discovered in other activities, such as sugarcane production, mining, factory work, and prostitution. See Human Rights Watch, Forced Labor in Brazil Rea visited: On Site Investigations Document that Practice Continues (1993), 2. 
cats) to recruit workers and make sure they do their work. ${ }^{6}$ The hierarchy's deliberate obfuscation of knowledge and responsibility operates to insulate the fazendeiro from liability for labour abuses. ${ }^{7}$

Lower demand for coffee and sugar and their replacement with mechanised soybean production in the 1960s, combined with endemic drought in Brazil's impoverished Northeast, have produced a mass of wandering and unskilled labourers known as peões de trecho. The gato specifically targets the poorest north-eastern states-especially Piauí and Maranhão-for potential recruits, enticing destitute peões with false promises of lucrative gains and good working conditions. ${ }^{8}$ The gato fronts the cost of transportation to the worksite and pays for food and lodging for the peôes along the way, creating from the very beginning a debtor-creditor relationship with the predominantly illiterate workers. ${ }^{9}$

At the fazenda, three coercive ingredients combine to create forced-labour conditions. First, the fazenda is extremely remote, typically hundreds of miles from the place of recruitment and far from towns in the region; the fazenda's isolation and a paucity of transportation infrastructure deprive the worker of any geographical orientation and make it difficult to find help even if he manages to escape. ${ }^{10}$ The second factor relates to the first: in the absence of feasible alternative sources, the worker must buy food, medicine, and work-related items at the company store located on the fazenda; the agent in charge of the store runs a tab for each worker, to be discounted from the worker's wages. The empreiteiros and gatos deliberately fashion the system so that the worker never makes enough in any given week to pay off his debt: he arrives at the fazenda already in debt, and must immediately make several credit purchases (including boots and chainsaws) at perhaps twice the goods' fair market value. ${ }^{11}$ Moreover, according to Kevin Bales, the prevailing cultural attitude that ' $\mathrm{Ca}$ ] man has to leave in the right way with his debts settled' injects an added element of coercion into the

See Le Breton, supra note 3, att 77.

7 See K. Bales, Disposable People: New Slavery in the Global Economy (1999), 143.

- D. Frigo, 'Denúncia à ONU, Miséria, medo e cumplicidade; a receita do trabalho escravo no Brazil', Testimony Before the 19th Session of the UN Working Group on Contemporary Forms of Slavery, Geneva, April-May 1994, reprinted in A. Sutton, Trabalho escravo: Um elo na cadeia da modernização no Brasil de hoje (1994), 155, $157-159$.

- R. Cunha, Untitled paper describing modern slavery in Brazil (no year), 2 (on file with author). Eighty four percent of the workers freed from forced-labour conditions by the Labour Ministry in 2002 were illiterate. U. Campbell, 'Abolição que nunca existiu', Correio Braziliense (Brasilia), 14 December 2003.

10 R. Rezende Figueira, 'Trabalho escravo no Brasil', in Associação dos luizes Federais do Brasil (ed.), Anais do $17^{\circ}$ Encontro Nacional dos Juízes Federais (2001), 105, 108.

11 See Cunha, supra note 9, at 3; see also Bales, supra note 7 , at 135 . 
relationship. ${ }^{12}$ Finally, if isolation and debt do not generate enough pressure to keep the worker from fleeing, armed gunmen patrol the worksite and shoot or otherwise physically abuse attempted deserters. ${ }^{13}$

Fazenda agents care little, if at all, about the comfort and safety of the workers, and charcoal-making and deforestation are by nature very temporary; consequently, the peōes ${ }^{\prime}$ shelter typically consists of dirtmfloored plastic tents through which chickens, pigs, snakes, and malaria-infested mosquitoes pass at will. The work that the fazenda agents force the peões to do, moreover, presents hazards of its own for which peões almost never have protective gear, including chainsaw mishaps and mutilation by falling tree trunks in deforestation activities, and burns and smoke inhalation in charcoal operations. ${ }^{14}$ When the peōes finally finish the job, fazenda agents do not take them back to Piauí or Maranhão, but instead unload them in one of the towns in the region, either with no pay at all or with substantially less than what was promised. ${ }^{15}$ An alarming percentage of these ex forced labourers, unable to pay for the trip home and without alternative work options, ends up signing on with a subsequent gato, and the cycle repeats itself in perpetuity. ${ }^{16}$

The Pastoral Land Commission (Comissão Pastoral da Terra), the leading domestic nongovernmental organisation (NGO) dealing with labour exploitation in Brazil, ${ }^{17}$ estimates that at any given time some 40,000 Brazilians are working under conditions of forced labour, ${ }^{18}$ and University of São Paulo sociologist José de Souza Martins has set the number much higher at $85,000 .^{19}$ The Brazilian government has publicly admitted to the existence of 25,000 forced labourers, a

i2 Ibid. at 136. According to one peão, '[i]f a man owes money and he runs away, then of course they have to kill him. That's obvious.' Le Breton, supra note 3, at 180 (author's translation).

13 See Cunha, supra note 9, at 3. A taskforce headed by Brazilian sociologist losé de Souza Martins, focusing on 475 forced-labour cases from the 1990s, came up with the following statistics: $20.7 \%$ of all forced labourers had been killed, 24.3\% had been tortured, and $15.5 \%$ had been submitted to other types of humiliation, including sexuał violence. Brasiliense, supra note 2 .

14 See Bales, supra note 7 , at $130-131$.

15 Cunha, supra note 9 , at $3,{ }^{i 6}$ Bales, supra note 7 , at 129,139 . The rate at which ex forced labourers fall back into forced-labour situations is disturbingly high (at least 40 percent). See notes $144 m 148$ and accompanying text, infra.

16 Bales, supra note 7 , at 129, 139. The rate at which ex forced labourers fall back into forced-labour situations is disturbingly high (at least 40 percent). See notes $144-148$ and accompanying text, infra.

17 The CPT, which was set up by local Catholic bishops, uses its network of local churches and offices to investigate, document, and publicise situations of forced labour. Le Breton, supra note 3, at 145-146. See also P. Casaldáliga, Uma igreja da Amazônia em conflito com o latifúndio e a marginalização social (1972).

18 J. Sofia, 'Trabalho forçado soma 12,3 mi de vítimas, diz Olf', Folha de São Paulo, 12 May 2005. See also Ł. Rohter, 'Jungle Slaves of the Amazon', N.Y. Times, 14 luly 2002, D4.

19. Brazilians Chained to job, and Desperate', N.Y. Times, 10 August 1995, A1. See also O. G. Davidson, 'Heart of Darkness; Inside the Dangerous Race to Liberate Tens of Thousands of Slaves in Brazil', Rolling Stone, 25 August 2005 (citing sources estimating the number of Brazilian forced labourers at 100,000 ). 
figure which the International Labour Organization (ILO) has apparently accepted as reasonably accurate..$^{20}$ Despite its prevalence in the Amazon, however, very few Brazilians from the populous central and southern regions even know that forced labour still exists in their country; ${ }^{21}$ moreover, those who are aware often take the common view that '[i]t's better to have some work than die for lack of it. ${ }^{22}$

No one who appreciates the magnitude of the problem denies that forced labour, especially the brutal Amazonian variety, bears a strong resemblance to slavery, one of humankind's greatest abominations. And unfortunately Brazil is by no means the only country still suffering from this scourge: an ILO report on forced labour released in May 2005 asserts that at least 12.3 million people are victims of forced labour worldwide, ${ }^{23}$ and some of the more liberal estimates put this figure as high as 200 million. ${ }^{24}$ The modern manifestations of slavery take many different forms: $:{ }^{25}$ vestiges of chattel slavery persist in Mauritania and Sudan; ${ }^{26}$ Southeast Asia, Eastern Europe, and elsewhere have borne witness to a dramatic increase in traffic in women and children for purposes of forced prostitution and work in factories or as domestic servants; and bonded labour endures in many parts of South Asia, particularly in India and Pakistan. ${ }^{27}$ The ILO has placed Brazil alongside Mauritania, Sudan, Pakistan, India, Thailand, Haiti, Peru, and the Dominican Republic as having one of the world's most serious forced-labour problems. ${ }^{28}$

Yet even in the face of such alarming realities, public international lawyers seem to have largely ignored slavery and related practices in recent decades. With the noteworthy exception of the inclusion in the 1990 s of enslavement, sexual slavery, and forced prostitution in the Statutes of the International

20 See International Labour Organization, A Global Alliance Against Forced Labour: Global Report Under the Follow up to the ILO Declaration on Fundamental Principles and Rights at Work (2005), para. 190.

21 Indeed, even high ranking govemment officials manifest a lack of awareness. For example, former Chief Labour Judge Francisco Fausto openty admits that, prior to taking charge of the Superior Labour Tribunal (Tribunal Superior do Trabalho) in 2001, he was ignorant of forced labour's continued existence. Fausto has since become one of the most vociferous activists in Brazil's anti-forced-labour campaign. See R. Gomide, 'Confiscar terra, a nova Lei Áurea: Entrevista com Francisco Fausto, presidente do Tribunal Superior do Trabalho', Jornal O Dia (Rio de Janeiro), 23 November 2003.

22. Frigo, supra note 8 , at 758 (author's translation).

2.3 International Labour Organization, supra note 20, para. 37.

24 See, e.g., A. Y. Rassam, 'Contemporary Forms of Slavery and the Evolution of the Prohibition of Slavery and the Slave Trade Under Customary International Law', (1999) 39 Virginia lournal of International Law 303 , at 305 .

25 See ibid. at 317, 326-327. See also P. Venetis, 'International Sexual Slavery', (1997) 18 Women's Rights Law Reports 263, at 268-269.

${ }^{26}$ See, e.g., Human Rights Watch, Children in Sudan: Slaves, Street Children and Child Soldiers (1995), avaliable at hitp://www.hrw.org/reports/1995/Sudan.htm.

27 See, e.g., Human Rights Watch, Small Change: Bonded Child Labor in India's Silk industry (2003), available at http:/www hrw.org/reports/2003/india/; Human Rights Watch, Contemporary Forms of Slavery in Pakistan (1995), available at http:/www.hrw.org/reports/1995/Pakistan.htm.

28 Le Breton, supra note 3 , at 233 . 
Criminal Tribunal for the former Yugoslavia (ICTY $)^{29}$ and Rwanda (ICTR), ${ }^{30}$ and that of the International Criminal Court ( $\mathrm{CCC})^{31}$ the last substantial alteration to the international legal regime governing the manifestations of slavery took place in 1957.32 Most of the leading treatises on human rights law make extremely cursory mention of the subject, typically only in the context of the nineteenthcentury anti-slavery movement as an antecedent of modern human rights law or when citing the anti-slavery norm as an example of jus cogens. ${ }^{33}$ There is additionally a dearth of case law on slavery and forced labour, with just five relevant cases having come out of the European Court and Commission of Human Rights since the inception of the Council of Europe human rights system. ${ }^{34}$ Fuelling the misconception that slavery has been 'dealt with' may be the fact that international stigmatisation of traditional chattel slavery and the African slave trade in the nineteenth century led long ago to a remarkably positive outcome. ${ }^{35}$ Both have been almost universally abolished in national legal systems for more than 100 years, ${ }^{36}$ and their occurrence in the modern day has dwindled to relatively few cases (for example, in Sudan and Mauritania) notwithstanding the absence of international enforcement machinery. ${ }^{37}$

Even international criminal law scholars fail to fully acknowledge the contemporary relevance of slavery and related practices. M. Cherif Bassiouni, for example, produced a draft international criminal code and commentary in 1987 in which the section entitled 'Slavery and Related Crimes' appears as a

29 Statute of the International Criminal Tribunal for the former Yugoslavia, SC Res. 827, UN Doc. S/RES/827 (1993), Annex, Arts. 2(e), 5(C), reprinted in (1993) 32 ILM 1203 thereinafter ICTY Statute].

30 Statute of the International Criminal Tribunal for Rwanda, SC Res. 955, UN Doc. S/RES/955 (1994), Annex, Arts. 3(c), 4(e), reprinted in (1994) 33 ILM 1602 [hereinafter [CTR Statute].

35 1998 Rome Statute of the International Criminal Court, 17 July 1998, Arts. $7(1)(c), 7(1)(\mathrm{g}), 8(2)(\mathrm{b})(\mathrm{xxii})$, UN Doc. A/CONF. 183/9 (1998) thereinafter Rome Statute].

32 1957 Convention Concerning the Abolition of Forced Labour (No. 105), 25 June 1957, 320 UNTS 291 [hereinafter 1..O Convention No. 105].

33 See, e.g., H. I. Steiner and P. Alston, International Human Rights in Context: Law, Politics, Morals 127 $(2000)(1,497$ pages with a single mention of slavery and slave trade and no mention of forced labour $)$ L. B. Sohn and T. Buergenthal, International Protection of Human Rights (1973) $(1,402$ pages with a handful of passing references to anti-slavery conventions and the anti-slavery norm as jus cogens); A. Cassese, Human Rights in a Changing World (1990) (two mentions of slavery, no mention of forced labour, in 245 pages); H. Lauterpacht, International Law and Human Rights (1968) (475 pages with a single page-and-ahalf discussion of slavery and forced labour in the context of the International Bill of the Rights of Man); T. Buergenthal and D. Shelton, Protecting Human Rights in the Americas (1995) (single mention of slave trade, no mention of slavery or forced labour, in 692 pages). For a noteworthy exception to this general trend of neglect of slavery and forced labour, see M. S. McDougal et al., Human Rights and World Public Order: The Basic Policies of an International Law of Human Dignity (1980), 475-508 (extensive 34-page analysis of evolution of anti-slavery and anti-forced-labour human rights regimes). See notes $84-88$ and accompanying text, infra.

35 See O. Patterson, Slavery and Social Death: A Comparative Study (1992), 148-171.

36 See note 52 and accompanying text, infra.

37 M. C. Bassiouni, International Criminal Law Conventions and Their Penal Provisions (1997), 638 [hereinafter Bassiouni 1997]. 
verbatim copy of the same section from his 1980 code, ${ }^{38}$ despite at least one significant development in the interim: in 1983 the European Court of Human Rights had occasion to construe the forced-labour provision in the European Convention, ${ }^{39}$ partially overruling a previous Commission case which Bassiouni cites - in 1980 as well as in 1987 -as authoritative. ${ }^{40}$ In similar fashion, Professor Bassiouni published an article in 1991 comprehensively laying out the international conventions touching on slavery and related practices, mentioning enslavement as a crime against humanity and a war crime in the Nuremberg ${ }^{4}$ and Tokyo Charters ${ }^{42}$ but, of course, making no mention of the not yet existing Statutes of the ICTY, the ICTR, and the ICC. He reproduced this article word for word in a chapter of a book released in 1999, omitting all reference to the slavery-related provisions which appear in the ICTY, ICTR, and ICC Statutes, all of which existed by 1999.43 And Professor Bassiouni is not alone: notwithstanding the status of slavery and the slave trade as two of the very first international crimes, none of the international conventions criminalising slavery, the slave trade, or forced labour appear in Christine van den Wyngaert's seemingly comprehensive collection of instruments on international criminal law. ${ }^{44}$

This article proceeds in Section 1 with a discussion of the very much neglected international legal regime governing slavery in its many manifestations when committed during peacetime. Specifically, it traces the contours of the slavery-related activities proscribed by conventional and customary international law, examining under which circumstances state responsibility and individual criminal responsibility may be engaged for the occurrence of such activities.

38 Compare M. C. Bassiouni, International Criminal Law: A Dratt International Criminal Code (1980) with M. C. Bassiouni, A Draft International Criminal Code and Draft Statute for an international Criminal Tribunal (1987).

39 1950 Convention on the Protection of Human Rights and Fundamental Freedoms, 4 November 1950, Art. 4(1), 213 UNTS 221 Thereinafter ECHR].

40 Compare Van der Mussele v. Belgium, [1983] 70 ECHR (Ser. A) with Iversen v. Norway, Appl, No. $1468 / 62$ (Eur. Comm'n H.R.), (1963) 6 Yearbook of the European Convention on Human Rights 278-332. See notes 84-88 and accompanying text, infra, for a more detailed discussion of these cases.

41 Charter of the International Military Tribunal for the Triat of the Major War Criminals, appended to Agreement for the Prosecution and Punishment of Major War Criminals of the European Axis, 8 August 1945, Art. $6(b)-(c), 59$ Stat. 1544, as amended, Protocol to Agreement and Charter, 6 October 1945 lhereinafter Nuremberg Charter].

42 Charter of the International Military Tribunal for the Far East, 19 lanuary 1946 (General Orders No. 1), Art. 5(c), as amended, General Orders No. 20, 26 April 1946, TIAS No. 1589, 4 Bevans 20 Ihereinafter Tokyo Charter].

4.3 Compare M. C. Bassiouni, 'Enslavement as an International Crime', (1991) 23 NVU Joumal of International Law and Politics 445 [hereinat́ter Bassiouni 1991] with M. C. Bassiouni, 'Enslavement', in M. C. Bassiouni (ed.), International Criminal Law (1999), Vol. 1, at 663.

44 See C. van den Wyngaert (ed.), International Criminal Law: A Collection of International and European Instruments (2005). 
The horrendousness of the human rights violations taking place in the Amazon has in the past 15 years drawn the focused attention of human rights advocates, Western powers, and potential investors. As a consequence, and after a great deal of recalcitrance, in the mid 1990s the Brazilian government finally began to invest human and financial resources into coming up with viable plans to solve the problem. Section 2 begins by discussing the innovative anti-forced-labour initiatives of the Fernando Henrique Cardoso (1995-2002) and Luiz Inácio Lula da Silva (2003 - present) administrations. Subsection 2.2 then explains how, due to a number of domestic political variables-such as the apathy and complicity of the federal and state judiciaries and the fazendeiros' pervasive influence in the national Congress-Brazil's laudable efforts have actually had little success in stamping out forced labour.

Section 3 commences with an examination of Brazil's potential state responsibility under international law. Specifically, it looks at whether Brazil could be held responsible for violating its obligations under the anti-slavery and human rights conventions to which it is a party, despite limited resources, other arguably more pressing human rights crises elsewhere in the country, the apparently private commission of the violations, and the extreme difficulty of monitoring and policing such remote and transitory activities. The section then proceeds to question whether holding the Brazillian state responsible and assessing monetary damages is in fact the most effective and fair way of dealing with the problem, and suggests that international criminal sanctions for the individual perpetrators of forced labour-and perhaps even prosecution in the ICC for crimes against humanity - could be a viable and preferable alternative. To this end, Subsection 3.2.2 explores the relatively meagre body of case law of the ad hoc International Criminal Tribunals-originating exclusively from the ICTY in just two cases-construing 'enslavement' as a crime against humanity. ${ }^{45}$

By way of conclusion, this article then discusses the broader implications for the international human rights movement of using international criminal law as a supplement or substitute for human rights law in curbing abuses endemic to the more remote and lawless corners of the globe.

45 See ICTY Statute, supra note 29, Art. 5(c); ICTR Statute, supra note 30, Art. 3(c). See also Prosecutor v. Kunarac, Kovaè, and Vukoviæ, Judgement, Case No. IT-96-23 \& M-96-23/1-A, 22 February 2001 thereinafter Kunarac et al. Trial Judgmentl; Prosecutor v. Krnojelac, Judgement, Case No. TT-97-25-T, 15 March 2002 thereinafter Kmojelac Trial Judgment; Prosecutor v. Kunarac, Kovà, and Vukoviæ, Judgement, Case No. IT-96-23 \& IT-96-23/1-A, 12 June 2002 [hereinafter Kunarac et al. Appeal Judgment]; Prosecutor v. Kmojelac, Judgement, Case No. IT-97-25 A, 17 September 2003 [hereinafter Kmojelac Appeal Judgment. 


\section{The international legal regime governing slavery and related activities}

\subsection{Slavery, the slave trade, slavery-like practices, and forced labour as internationally wrongful acts entailing state responsibility}

\subsubsection{Specific instruments dealing with slavery-related activities}

Through an ongoing process which began in the early nineteenth century, the international community has issued a multitude of international declarations and conventions condemning various aspects of slavery and other coercive labour arrangements. Although several nineteenth-century instruments had outlawed the slave trade, ${ }^{46}$ the first instrument to deal comprehensively with slavery continues to be the central convention on the subject: the 1926 League of Nations Slavery Convention. ${ }^{47}$ Nevertheless, while the Convention's command to states parties to suppress slavery 'in all its forms' ${ }^{\prime 48}$ appears at first glance to encompass a broad range of conduct, the Convention's rather restrictive definition of 'slavery' in Article 1(1) effectively confines that which is prohibited to chattel slavery only: 'Slavery is the status or condition of a person over whom any or all of the powers attaching to the right of ownership are exercised. ${ }^{\prime 49}$ Moreover, the Convention bans forced labour exacted by non public entities, but it does not ban the practice for public purposes, merely cautioning states to take all necessary measures so that forced labour does not devolve into 'conditions analogous to slavery'. ${ }^{50}$

46 See 1815 Declaration Relative to the Universal Abolition of the Slave Trade, \& February 1815, 63 Consol. TS No, 473 (condemning the stave trade as 'repugnant to the principles of humanity and universal morality'); 1841 Treaty for the Suppression of the African Slave Trade, 20 December 1841, Art. 1, 92 Consol. TS No. 437 [hereinafter 1841 Treaty of London] (obliging states parties to 'prohibit all trade in slaves ... and to declare such trafic piracy'); 1890 Convention Relative to the Slave Trade and Importation into Africa of Firearms, Ammunition, Spirituous Liquor, 2 July 1890, Arts. II, XLII, 27 Stat. 886, TS No. 383 [hereinater 1890 Brussels General Act (banning slavery and the slave trade without defining them, and establishing a procedure for inspection, seizure, and adjudication of ships suspected of carrying slaves).

47 1926 Convention to Suppress the Slave Trade and Slavery, 25 September 1926, 212 UNTS 17 [hereinafter 1926 Slavery Convention. The 1926 Slavery Convention contains only 12 articles.

48 Ibid., Art. 2(b).

49 Ibid., Art. $1(1)$. This definition has remained authoritative up to the present day, making its most recent appearance in the crimes-against-humanity provision of the 1998 Rome Statute. Article $7(2)(\mathrm{c})$ defines 'enslavement' as the 'exercise of any or all of the powers attaching to the right of ownership over a person and includes the exercise of such power in the course of traficking in persons, in particular women and children.' Rome Statute, supra note 31, Art. $(7)(2)(\mathrm{c})$.

50 Ibid., Art. 5. Subsequent to the 1926 Convention, 'conditions analogous to slavery' became a term of ant, proscribed in many states' national laws and defined in considerable detail in Article 149 of the Brazilian Penal Code. See notes $158-162$ and accompanying text, infra. 
While chattel slavery and the slave trade still exist today-particularly in Sudan, ${ }^{51}$ Mauritania, and other parts of the Middle East and Africa-these two most traditional of the manifestations of slavery have largely receded in the wake of nineteenth-century national abolitions and the anti-slavery and anti-slave-trade conventions. ${ }^{52}$ Notwithstanding this remarkable progress, ${ }^{33}$ however, a joint UN ILO report produced shortly after the 1953 Protocol to the Slavery Convention ${ }^{54}$ came into force revealed that lessstraightforward guises of slavery continued to flourish in many parts of the world. ${ }^{55}$ In response, states in 1956 adopted the UN Supplementary Convention on the Abolition of Slavery, the Slave Trade, and Institutions and Practices Similar to Slavery. ${ }^{56}$ Intended as a supplement to the 1926 Convention, the 1956 Convention reaffirms the ban on chattel slavery ${ }^{37}$ and the slave trade, ${ }^{58}$ and further binds states parties to take measures to curb the so called institutions and practices similar to slavery', also known as 'slavery-like practices'; such practices exhaustively include debt bondage, serfdom, compulsory marital arrangements, and the sale of children into labour. ${ }^{59}$ The Convention labels the victims of slaverylike practices 'persons of servile status'. ${ }^{60}$

5: See, e.g., Interim Report on the Situation of Human Rights in tive Sudan Prepared by Mr. Gaspar Biro, Special Rapporteur of the Commission on Human Rights, in Accordance with Commission Resolution 1995/77 of 8 March 1995, UN Doc. A/50/569 (1995).

52 Rassam, supra note 24, at 317. See ałso 'Suppression of Slavery', (1931) 2 Geneva Special Studies No. 4, at 4. The following years of formal abolition of chattel slavery in various states and territories reveal a domino effect, starting with Britain and France: Britain $(1772 ; 1833$ in the colonies); France $(1791 ; 1848$ in the colonies); Austria (1811); Chile (1811); Peru (1821); Guatemala (1824); Dominican Republic (1844); Tunisia (1846); Sweden (1846); Denmark (1848); Hungary (1848); Ecuador (1851); Argentina (1853); Venezuela (1854); Portugal (1856); Russia (1860); Netherlands (1863); United States (1865); Cuba (1866); Puerto Rico (1872); Brazil (1888); Egypt (1896); Siam (1905); China (1909). See Bassiouni 1991, supra note 43, at 451452; see also MCDougal et al., supra note 33, at 490-491; US Constitution, amendment XIIl.

53 Professor Bassiouni hails slavery as unique among international crimes in that its near eradication has occurred without reliance on an international enforcement mechanism. He attributes this phenomenon to the coalescence and concurrence of 'the commonly shared values of the international community ... with the political will of states.' Bassiouni 1997 , supra note 37 , at 638 .

541953 Protocol to the 1926 Stavery Convention, 7 December 1953, 212 UNTS 17. The 1953 Protocol substituted UN agents and institutions for the League of Nations agents and institutions that appear in the 1926 text.

55 Rassam, supra note 24 , at 331.

56 1956 Supplementary Convention on the Abolition of Slavery, the Slave Trade, and Institutions and Practices Similar to Stavery, 7 September 1956, 226 UNTS 3 [hereinafter 1956 Supplementary Slavery Convention. ibid., Arts. 5-6.

Ibid., Art. 3.

Ibid., Art. 1(a)-\{d). 'Debt bondage' is 'the status or condition arising from a pledge by a debtor of his personal services or of those of a person under his control as security for a debt. 'Ibid., Art. I (a). 'Serfdom' is 'the condition or status of a tenant who is by law, custom or agreement bound to live and labour on land belonging to another person and to render some determinate service to such other person.' 'lbid., Art. 1(b). Proscribed compulsory marital arrangements include those in which '[a] woman ... is promised or given in marriage on payment of a consideration in money or in kind, ... a husband ... has the right to transfer this wife], or on the death of her husband, a woman is liable to be inherited'. Ibid., Ant. 1(c). 
As concerns state responsibility for perpetuating or permitting functional approximations to slavery, the 1956 Convention suffers from two major flaws that substantially reduce its effectiveness. First, the Convention does not oblige states parties to eliminate the four categories of proscribed conduct immediately, but merely calls on them to take 'all practicable and necessary legislative... measures to bring about progressively and as soon as possible' the abandonment of such practices. ${ }^{61}$ Secondly, the list of prohibited conduct is exhaustive, including only the four categories enumerated in Article 1 and leaving many other coercive practices untouched. Indeed, it would appear that the 1956 Convention does not prohibit the type of labour arrangement prevalent in the Brazilian Amazon. 'Debt bondage' requires a voluntary pledge by the debtor of his personal services as security for an existing debt. ${ }^{62}$ By contrast, when Brazilian workers sign up to work at a given fazenda, they do not yet owe money to the fazendeiro; the debt arises later when, to his surprise, the worker must purchase the needed food, clothing, and equipment on credit. Only then does the worker perform his duties in order to liquidate an existing debt, and he must render such services whether he wants to or not.

The 1926 Slavery Convention is the first international instrument to deal with forced labour, providing in Article 5(1) that 'compulsory or forced labour may only be exacted for public purposes. ${ }^{163}$ Article 5(2) makes an exception, however, for 'territories in which compulsory or forced labour for other than public purposes still survives', but even in such territories forced labour must be of an exceptional character and adequately remunerated. ${ }^{64}$ Moreover the Convention, by calling on states parties to 'take all necessary measures to prevent compulsory or forced labour from developing into conditions analogous to slavery', seems to recognise that forced labour does not suffer from the same level of egregiousness as slavery. ${ }^{65}$

ILO Convention No. 29 of $1930^{66}$ prohibits the use of forced or compulsory labour for non-public purposes in no uncertain terms, and calls upon states to suppress all public forms of such labour 'within the shortest possible period. ${ }^{67}$ It defines 'forced or compulsory labour' as 'all work or service which is exacted from any person under the menace of any penalty and for which the said person has not offered himself voluntarily. ${ }^{168}$ Article 2 proceeds,

\footnotetext{
G) [bid., Art, 1 (emphasis added).

62 lbid., Ait. 1(a).

631926 Slavery Convention, supra note 47 , Art. 5(1).

bu lbid., Art. 5(2),

65 bbid., Art. 5; see also ibid., pmbl.

66 1930 Convention Conceming Forced or Compulsory Labour (No. 29), 28 lune 1930, 39 UNTS 55 [hereinatter ILO Convention No. 291. Almost from the moment of its inception, the ILO began a rigorous and stil:ongoing campaign to curtail and ultimately eliminate the use of forced labour in the world.

67 lbid., Art, 1(1)-(2).

的 Ibid, Art. 2(1).
} 
however, to exempt a number of practices from the purview of forced or compulsory labour, including mandatory military service, work which forms part of normal civic obligations, hard prison time, and work exacted in situations of emergency. ${ }^{69}$ In all other cases where public officials have recourse to forced or compulsory labour, Convention No. 29 imposes important restrictions by, for example, limiting those who can be called upon to work to able-bodied adult males, and mandating that the working hours and pay of forced labourers be comparable to those of free labourers performing the same job. ${ }^{70}$

Nearly three decades after Convention No. 29 the ILO produced a supplementary forced-labour convention-Convention No. 105 of $1957^{71}$-in response to the findings of the UN ILO Ad Hoc Committee on Forced Labour that many states had been using 'corrective' forced labour as a means of political coercion..$^{72}$ The Convention obliges states parties to adopt effective measures for the immediate and complete abolition of any form of forced or compulsory labour for certain specified purposes, including as a means of coercion or political education; workplace discipline; social, national, or religious discrimination; as a method of mobilisation and utilisation of labour for economic means; or as a punishment for having participated in strikes. ${ }^{73}$

\subsubsection{General human rights treaties proscribing slavery-related activities}

Several of the general international human rights instruments contain a prohibition on slavery and the practice deemed 'servitude'. Article 4 of the 1948 Universal Declaration of Human Rights (UDHR) provides that 'In]o one shall be held in slavery or servitude', and that 'slavery and the slave trade shall be prohibited in all their forms. ${ }^{174}$ Likewise, the 1966 International Covenant for Civil and Political Rights (ICCPR), ${ }^{75}$ as well as the 1969 American Convention on Human Rights (ACHR), ${ }^{76}$ forbid slavery, the slave trade, and servitude, and the ACHR goes further to prohibit 'traffic in women'. Curiously, the analogous provision of the 1950 European Convention on Human Rights (ECHR) ${ }^{77}$ makes no specific mention of the slave trade, although its proscriptions of slavery

69 Ibid., Art. 2(2)(a)-(e).

$x$ lbid., Arts. 11(1), 13(1), 14(1).

71 ILO Convention No. 105, supra note 32.

72 See United Nations and Internationat Labour Office, Report of the Ad Hoc Committee on Forced Labour, UN DoC. E/2431 (1953).

73 LO Convention No. 105, supra note 32, Art. 1(a)-m(e). The Convention's preamble reiterates the plea of the 1926 Slavery Convention for states to lake all necessary measures to prevent forced labour from degrading into conditions analogous to siavery. Ibid, pmbi.

741948 Universal Declaration of Human Rights, GA Res. 217A, Art, 4, UN GAOR, UN DOC. A/810 (1948).

7s 1966 International Covenant for Civil and Political Rights, 16 December 1966, Arts. 8(1)-n(2), 999 UNTS 171 [hereinafter [CCPR].

\% 1969 American Convention on Human Rights, 22 November 1969, Art. 6(1), 1144 UNTS 123 [hereinafter ACHR].

77 ECHR, supra note 39, Art. 4(1). 
and servitude doubtless imply the impermissibility of the slave trade. ${ }^{78}$ All three conventions disallow derogation from the anti-slavery and anti-servitude norms in times of public emergency. ${ }^{79}$ Moreover, while neither the UDHR nor any of the general human rights conventions define slavery or servitude, the travaux préparatoires of the ICCPR suggest that the drafters intended servitude to be a more flexible notion than slavery, encompassing the 'slavery-like practices' defined in the 1956 Supplementary Convention and possibly extending to other severe forms of domination of one human being over another. ${ }^{80}$

The ICCPR, ECHR, and ACHR each contain an explicit prohibition on forced or compulsory labour. ${ }^{81}$ Nevertheless, following the example of Conventions No. 29 and 105, the prohibition is not absolute, and the three conventions all contain essentially the same list of exemptions as that laid out in Convention No. $29{ }^{82}$ The strength of the anti-forced-labour norm in the ICCPR and ECHR is further weakened by its derogability in times of public emergency; perhaps owing to Latin America's unhappy history with abusive invocations by public officials of emergency powers, only the ACHR forbids derogation from the anti-forced-labour norm as well as the anti-slavery, anti-slave-trade, and anti-servitude norms. ${ }^{83}$

As with slavery and servitude, none of the conventions defines 'forced or compulsory labour'. The European Court of Human Rights had a rare opportunity to elaborate on the substance of the practice, however, in the 1983 case of Van der Mussele v. Belgium. ${ }^{84}$ in conformity with Article 2(1) of Convention No. 29,

78 McDougal et al. supra note 33, at 502.

79 ICCPR, supra note 75, Art. 4(2); ECHR, supra note 39, Art. 15(2); ACHR, supra note 76, Art. 27(2). Additionally, the 1981 African Charter on Human and Peoples' Rights contains a general provision forbidding 'all forms of degradation of man', including slavery and the slave trade, but makes no specific mention of servitude. 1981 African Charter on Human and Peoples' Rights, 27 june 1981, Aft. 5, Doc. OAU/CAB/LEG/ $67 / 3 /$ Rev.5, (1982) 21 HLM 59.

(10) See Annotations on the Text of the Draft International Covenants on Human Rights, 10 UN GAOR, Annexes (Agenda Item 28) 33, UN Doc. A/2929 (1955). See also M. Nowak, UN Covenant on Civil and Political Rights, CCPR Commentary 148 (1993); N. Lassen, 'Slavery and Slavery-Like Practices: United Nations Standards and Implementation', (1988) 57 Nordic Journal of International Law 197, at 207 (outlining the slavery-like practices identified in the 1956 Supplementary Slavery Convention). The Human Rights Committee viewed US proposais to substitute the tem 'servitude' in the ICCPR with 'peonage or serfdom' or 'involuntary servitude' as too narrow because they would fail to protect individuals who voluntarily contract themselves into bondage. Nowak, supra, at 148.

31 ICCPR, supra note 75, Art. 8(3); ECHR, supra note 39, Att. 4(2); ACHR, supra note 76, Art. 6(2).

32 ILO Convention No. 29, supra note 66, Art. 2(1)\{a)-(e); ICCPR, supra note 75, Art. 8(3)(c)(j)-(iv); ECHR, supra note 39, Art. 4(3)(a)-(d); ACHR, supra note 76, Art. 6(3)(a)-(d). Those exemptions are compulsory military service, hard labour, service exacted during times of national emergency, and any other work or service that forms part of normal civic obligations (for example, jury duty). See also lLO Convention No. 29, supra note 66, Art. 2(2)(a)-(e).

83 lbid., Art. $27(2)$.

84 Van der Mussele v. Belgium, supra note 40. The Court noted that it would rely on Convention No. 29 in interpreting Article 4 of the ECHR, especially since the architects of the ECHR had had that convention in particular mind during the drafting process. Ibid., para. 32. 
for a given labour situation to constitute a violation of ECHR Article 4 it must be exacted under the menace of a penalty and against the will of the person concerned. ${ }^{85}$ Hence, a work obligation based on a prior contract or other voluntary agreement probably does not amount to forced or compulsory labour..$^{86}$ Moreover, according to the European Court, the coercion exerted upon the worker need not be physical: mental constraint may also lead to forced labour. ${ }^{87}$ Such constraint almost certainly includes the psychological pressure placed upon Brazilian labourers by indebting them to the fazendeiro. In addition, in certain circumstances even remunerated work can fall into the category of 'forced or compulsory', particularly if the duties performed are excessive or disproportionate to the advantages attached to the profession..$^{88}$

Upon examination of the general and specific human rights conventions which deal in some way with the various manifestations of slavery, one can clearly identify a hierarchy whereby the more egregious deprivations of human liberty and dignity engage more absolute proscriptions. Thus, slavery and the slave trade are prohibited in all circumstances, with no exceptions or derogations. Slaverylike practices and servitude also permit no derogations, but the 1956 Supplementary Convention only enumerates four broad categories of such practices, and merely obliges states to take 'practicable' measures to do away with the practice 'as soon as possible'. ${ }^{89}$ And while international agreements place strict limitations on states' use of forced labour and prohibit its use for non state entities and private individuals, they do not ban it outright: the ICCPR and ECHR allow derogations in times of public emergency, and all formulations exempt certain practices from forced labour's scope. Moreover, forced or compulsory labour requires involuntariness; by contrast, potential victims of violations of the 1956 Supplementary Conventionsuch as those willing to contract themselves into bondage in order to pay off an existing debt-enjoy protection whether or not they offer themselves voluntarily for the bonded condition.

s. Ibid., para. 34.

sh 'Comment', in R. A. Lawson and H. G. Schermers (eds.), Leading Cases of the European Court of Human Rights $\langle 1999$, 143.

87 Van der Mussele v. Belgium, supra note 40, para. 33.

as lbid., paras. 36, 40. See also 'Comment', supra note 86, at 143. While Article 4 cases are rare, the European Court and Commission have construed the provision on at least four other occasions. See lversen $v$. Norway, supra note 40; X v. the Netherlands, Appl. No. 7602/76 (Eur. Comm'n H.R.). [1976] 7 DR 161-163; Van Droogenbroeck v. Bejgium, [1982] 50 ECHR (Ser. A); Schmidt v. Germany, [1994] 291-B ECHR (Ser. A). See also María Mejía v. Guatemala, Case 10,553, Inter-Am. C.t. H.R., OEA/Ser.1/N/H.95, doc. 7 rev. at 370 (report no. 32/96) (1997). 


\subsubsection{Slavery-related activities under customary international law}

No state today claims the right to make use of slavery, the slave trade, or slavery-like practices. National laws and a multitude of international declarations and conventions (including international humanitarian law conventions ${ }^{90}$ ) denounce these activities, and their perpetration has dwindled to relatively few acts carried out by private individuals. These developments leave little room for doubt that the requisite state practice and opinio juris exist to place the norms against slavery, the slave trade, and slavery-like practices squarely within the realm of customary international law. ${ }^{93}$ Accordingly, any state acquiescence in slavery, the slave trade, or slavery-like practices gives rise to state responsibility, regardless of whether the state has ratified any of the applicable conventions. ${ }^{92}$

Based on this universal condemnation, the International Court of Justice has singled out slavery, along with protection from racial discrimination, as examples of rules concerning the basic rights of the human person that give rise to obligations erga omnes, that is, 'obligations of a State toward the international community as a whole' ${ }^{93}$ As a consequence any state in the world, and not just a state whose national has fallen victim to an act of enslavement, has standing to invoke the offending state's responsibility. ${ }^{94}$ Furthermore, slavery, the slave trade, and slavery-like practices have almost certainly joined the ranks of torture, piracy, and genocide as jus cogens violations, ${ }^{95}$ especially given

90 See, e.g., 1949 Geneva Convention Relative to the Protection of Civilian Persons in Time of War, 12 August 1949, Art. 147, 75 UNTS 287 (listing compelled service of a protected person in the forces of a hostile power as a grave breach); 1977 Protocol Additional to the Geneva Conventions of 12 August 1949, and Relating to the Protection of Victims of Non International Armed Conflicts (Protocol \{l), 12 December 1977, Aft. 4(2)(f), 1125 UNTS 609 ('slavery and the slave trade in all their forms ... are and shall remain prohibited at any time and in any place whatsoever').

31 See Bassiouni 1991, supra note 43, at 445.

${ }^{92}$ See Report of the Working Group on Contemporary Foms of Slavery on lts Twenty first Session, UN Doc. Ef CN.4/Sub.2/1996/24 (1996), at 21 .

93 Barcelona Traction, Light and Power Co. Ltd. (2d Phase) (Belgium v. Spain), ) udgment of 5 February 1970 , [1970] [C] Rep. 3, at 32. The Court additionally included the noms against genocide and aggression as giving rise to erga omnes obligations. lbid.

94 Draft Articles on Responsibility of States for intemationally Wrongful Acts, in Report of the international Law Commission on the Work of its Fifly third Session, Art. 48, UN Doc. A56/10 (2001) Thereinafter Draft Articles].

95 The term 'jus cogens' refers to a group of peremptory norms in customary international law that are so important to the international community that they remain binding notwithstanding any agreement to the contrary. 1969 Vienna Convention on the Law of Treaties, 23 May 1969, Art. 53, (1969) $811 \mathrm{M} 679$, at 698. See also Reports of the Anternational Law Commission on the Second Part of Its Seventeenth Session and on its Eighteenth Session, UN Doc. A/6309/Rev. 1 (1966), reprinted in (1966) 2 Yearbook of the International Law Commission 247-248 (induding anti-slavery norm in the list of jus cogens norms); Restatement (Thidd) of the Foreign Relations Law of the United States $\$ 702 \mathrm{~cm}$. a (1987) (recognising the prohibition against slavery and the slave trade as jus cogens norms) hhereinafter Restatement; United States $v$. Matta-Ballesteros, 71 F.3d 754, 764 n.5 (9th Cir. 1995) (describing torture, murder, genocide, and slavery as jus cogens norms); Filartiga v. Peña-krala, 630 F.2d 876,890 (2d. Cir. 1980) (calling the slave trader hostis humanis generis'-an enemy of all mankind). 
that none of the specific or general human rights instruments allows derogation from the norms prohibiting them. ${ }^{96}$

The norm prohibiting forced labour likely also forms part of customary international law, but in less absolute terms than the norms against slavery, the slave trade, and slavery-like practices. ${ }^{97}$ A sizable majority of states has ratified Conventions No. 29 and 105 (indeed, they are the two most widely ratified of the ILO's 185 conventions $^{98}$ ), and few states make use of or acquiesce in forced labour that does not fall into one of the exemptions allowed by the ILO Conventions and the general human rights instruments. ${ }^{99}$ Nevertheless, while several authorities have summarily asserted that the anti-forced-labour norm rises to the level of jus cogens, ${ }^{100}$ and forced labour in violation of Conventions No. 29 and 105 probably constitutes an international crime, ${ }^{101}$ it is actually quite questionable whether the norm enjoys peremptory status. One of the central attributes of a jus cogens norm, in terms of Article 53 of the 1969 Vienna Convention on the Law of Treaties, is that it allows for no derogation. ${ }^{102}$ The ICCPR and ECHR-but, importantly, not the ACHR-allow for derogation from the anti-forced-labour norm in times of public emergency. ${ }^{103}$

36 ICCPR, supra note 75, Art. 4(2); ECHR, supra note 39, Art. 15(2); ACHR, supra note 76, Art. 27(2).

97 See R. Jennings and A. Watts (eds.), Oppenheim's International Law (1992), 982. See also Rassam, supra note 24, at 308; M. C. Bassiouni, Crimes Against Humanity in International Criminal Law (1999), 309 ("No one could doubt ... that even before 1945, submitting a person to slavery or slave-related practices, including forced labor, constituted a violation of "general principles of law".').

98 International Labour Organization, supra note 5, para. 32. As of October 2005, 1LO Convention No. 29 had 168 states parties, and ILO Convention No. 105 had 165 states parties. A list of states parties is available at http://www.ilo.org/ilolex/english/newratframeE.htm.

99 See S. Cleveland, 'Global Labor Rights and the Alien Tort Claims Act', (1998) 76 Texas Law Review 1533, at 1571 (The prohibition of forced labor and slave-like practices are now widely recognised in conjunction with slavery as customary international norms'). See also Jennings and Watts, supra note 97, at 982; L. Henkin, "Human Rights and State "Sovereignty", (1995-1996) 25 Georgia foumal of International and Comparative Law 31 , at 37.

ioo See, e.g., Doe v. Unocal Corp., 395 F.3d 932, 945 (9th Cir. 2002) ('forced labor is so widely condemned that it has achieved the status of a jus cogens violation'); Report of the Commission of Inquiry Appointed Under Article 26 of the Constitution of the International Labour Organization to Examine the Observance by Myanmar of the Forced Labor Convention, 1930 (No. 29), 2 July 1998, para. 203, available at hitp:// www.ilo.org/public/english/standards/relm/gb/docs/gb273/myanmar.htm ('there exists now in intenational law a peremptory norm prohibiting any recourse to forced labour').

101 See, e.g., ILO Convention No. 29, supra note 66, Art. 25 (requiring states to make forced labour 'punishable as a penal offense'). See also notes $111-115$ and accompanying text, infra.

302 Vienna Convention on the Law of Treaties, supra note 95, Art. 53.

103 ICCPR, supra note 75, Art. 4(2); ECHR, supra note 39, Art. 15(2); ACHR, supra note 76, Art. 27(2). See also Restatement, supra note $95, \$ 702 \mathrm{cmt}$. a (omitting forced labour from a non-exhaustive list of jus cogens norms). 


\subsection{Slavery, the slave trade, slavery-like practices, and forced labour as international crimes entailing individual criminal responsibility}

\subsubsection{Slavery-related activities as freestanding international crimes}

Professor Bassiouni identifies two requirements for internationally circumscribed conduct to rise to the level of an international crime: such conduct must either amount to an offence against the entire international community, or interstate cooperation must be necessary for the effective suppression of the conduct, or both. ${ }^{104}$ Yet beyond the four so called 'core crimes' of genocide, crimes against humanity, aggression, and war crimes, determining which acts constitute international crimes is no easy task. International conventions seldom proclaim explicitly that the acts they proscribe constitute international crimes, and no all-encompassing list of international crimes exists. Therefore, according to Bassiouni, one must look for certain features in an international instrument in order to discern whether its drafters intended to internationally criminalise the behaviour spelled out therein; the most typical of these features are the right or duty to make the conduct a crime under national law, the right or duty to prosecute or extradite offenders, the right or duty to punish offenders, and the duty to cooperate with and render assistance to other states parties in the suppression of the conduct. ${ }^{105}$ The presence of one or more of these features in several of the anti-slavery and anti-forced-labour conventions provides the most solid evidence that slavery, the slave trade, slavery-like practices, and many forms of forced labour constitute international crimes.

Among these four categories, the slave trade most clearly qualifies as an international crime. It ranks alongside piracy as one of the very first international crimes giving rise to universal jurisdiction, ${ }^{106}$ and as early as 1841 the Treaty of London established a duty on states parties to prohibit, prevent, prosecute, and punish the slave trade. ${ }^{107}$ The 1926 and 1956 Slavery Conventions reiterate the

304 M. C. Bassiouni, 'The Penal Characteristics of International Criminal Law', (1983) 15 Case Westem Reserve fournal of International Law 27, 28-29.

:05 See M. C. Bassiouni, International Crimes: Digest/Index of Intemational Instruments 1815-1985 (1986), Vol. 1, at $l v$. The following is the full list of Bassiouni's ten features: (1) explicit recognition of proscribed conduct as constituting an international crime, or a crime under international law, or a crime; (2) implicit recognition of the penal nature of the act by establishing a duty to prohibit, prevent, prosecute, punish, or the like; (3) criminalisation of the proscribed conduct; (4) duty or right to prosecute; (5) duty or right to punish the proscribed conduct; (6) duty or right to extradite; (7) duty or right to cooperate in prosecution and punishment (including judicial assistance); (8) establishment of a criminal jurisdictional basis; (9) reference to the establishment of an international criminal court or intemational tribunal with penal characteristics; (10) no defence of superior orders. Ibid.

106 C. de Than and E. Shorts, International Criminal Law and Human Rights (2003), 264.

1071841 Treaty of London, supra note 46 , Arts. $1,111, \mathrm{~V} \mid-\mathrm{V} \| \mathrm{X}, \mathrm{XV}$. 
obligation on states parties to criminalise the slave trade and prosecute those who trade in slaves, and the 1956 Convention labels such trade a 'criminal offence'. ${ }^{108}$

Slavery and slavery-like practices doubtless also give rise to international criminal responsibility. Article 6 of the 1926 Slavery Convention obliges states parties to 'undertake to adopt the necessary measures in order that severe penalties may be imposed' for placing or maintaining someone in the condition of chattel slave, and Article 4 establishes a duty on states parties to grant each other assistance in securing the abolition of slavery. ${ }^{109}$ The 1956 Supplementary Slavery Convention likewise sets forth the obligation to criminalise and prosecute the act of enslavement, as well as the act of placing someone into a 'servile status' by means of debt bondage, serfdom, etc., and that of 'mutilating, branding or otherwise marking a slave or a person of servile status.'110

Like slavery, the slave trade, and slavery-like practices, the conventions that define forced labour also contain certain features that evince its qualification as a 'freestanding' crime under international law - that is, an activity recognised as internationally criminal even where it is not a predicate offence to one of the core crimes of genocide, war crimes, and crimes against humanity-but in less absolute terms. Article 5 of the 1926 Slavery Convention prohibits the use of forced labour for private purposes unambiguously; when read in conjunction with Article 6's duty to criminalise and prosecute infractions of the 1926 Convention, this prohibition could be construed as making any private use of forced labour-regardless of the reasons for such use-internationally criminal. " 1 ILO Convention No. 29 repeats the prohibition on forced labour for private purposes, ${ }^{112}$ but allows it for public purposes subject to a number of conditions and guarantees designed to make the conditions of the forced labour as much like those of voluntary labour as possible, such as normal working

3081926 Slavery Convention, Supra note 47, Art. 3; 1956 Supplementary Slavery Convention, supra note 56, Art. 3. The 1958 Geneva Convention on the High Seas and the 1982 un Law of the Sea Convention each contain similar provisions. See 1958 Geneva Convention on the Law of the Sea, Art. 13, 450 UNTS 82 , reprinted in (1958) 52 All 842; 1982 UN Convention on the Law of the Sea, Art, 99, UN Doc. AVCONF.62/ 122 (1982), reprinted in(1982) 21 ILM 1261.

Ing 1926 Slavery Convention, supra note 47 , Arts. 4, 6.

:11 1956 Supplementary Slavery Convention, supra note 56, Arts, 5-6. In addition, Article 8 of the 1956 Convention establishes a duty or right of states parties to cooperate with each other and with the United Nations in the prosectition and punishment of slavery, the slave trade, and slavery-like practices. Ibid., Art. 8. Slavery has even been put forth as an act which could give rise to state criminal responsibility, constituting along with genocide and apartheid 'a serious breach of an international obligation of essential importance for safeguarding the human being.' See Draft Articles on State Responsibility Adopted So Far by the International Law Commission, Art. $19(3)(\mathrm{c})$, reproduced in J. H. W. Weiler et al. (eds.), International Crimes of State (1989), 360.

"1926 Slavery Convention, supra note 47, Arts. 5-6.

112. LOO Convention No. 29, supra note 66, Arts. 1(2), 4(1). 
hours, safe conditions, and remuneration at the same rate as free labour. Moreover, the work must be necessary, in the direct interest of the community, and must not place too heavy a burden on the population. ${ }^{113}$ Recall as well that Article 2 of Convention No. 29 completely exempts from the scope of 'forced or compulsory labour' several practices, such as military and community service and hard prison time. ${ }^{114}$ As a result of these exceptions and exemptions, Article 25's duty to criminalise, prosecute, and punish extends only to the illegal exaction of forced or compulsory labour'.115

Presumably, then, only 'illegal' forms of forced labour rise to the level of international crimes, including forced labour exacted by private individuals and any other recourse to forced labour in violation of the detailed conditions and guarantees laid out in Convention No. 29, but not including exempted conduct such as compulsory military service. Thus, the 1926 Slavery Convention and Conventions No. 29 and 105 appear to establish a continuum whereby the further the conditions of the forced labour are from those of free labour, the more likely such labour constitutes a violation of international law and, in the extreme, an international crime. Three factors stand out as most directly contributing to the conversion of permissible forced labour into criminal forced labour: its non public nature, more total control over the worker's life, and the inhumanity of the conditions to which the worker is subjected. ${ }^{116}$ Many commentators' accounts of typical Amazonian forced-labour conditions would seem to place it in this category. 17

\subsubsection{Slavery-related activities as crimes against humanity}

An act deemed 'enslavement' has appeared as a predicate offence of crimes against humanity in every international instrument listing such crimes since Article 6(c) of the 1945 Nuremberg Charter. ${ }^{118}$ The Nuremberg Tribunal

\footnotetext{
113 Ibid., Arts. 11-19. See also Bassiouni 1991, supra note 43, at 470 471 .

11\% ILO Convention No. 29, supra note 66, Art. 2(2)(a)-...(e).

115 tbid., Art. 25 (emphasis added).

1 it See S. R. Ratner and I. S. Abrams, Accountability for Human Rights Abuses in International Law: Beyond the Nuremberg Legacy (2001), 115. See also Bassiouni 1991, supra note 43, at 456, 459, 471; Rassam, supra note 24 , at $341-342$.

117 See, e.g., Bales, supra note 7, at 130-131; Sutton, supra note 8, at 118.

iis See, e.g., Nuremberg Charter, supra note 41, Art. 6(c); Tokyo Charter, supra note 42, Art. 5(c); Control Council Law No. 10, Art. Il(1)(c), in Official Gazette of the Control Council for Germany (1946), Vol. 3, at 50; Draft Code of Offences Against the Peace and Security of Mankind (1954), Art. 2(11), reprinted in(1954) 2 Yearbook of the International Law Commission 151, UN Doc. A/2693 (1954) Thereinafter 1954 Draft Code]; Draft Code of Crimes Against the Peace and Security of Mankind (1991), Art. 21, in Report of the International law Commission on the Work of Its Forty third Session, UN Doc. A/46/10 (1991) [hereinafter 1991 Draft Code]; Draft Code of Crimes Against the Peace and Security of Mankind (1996), Art. 18(d), in Report of the International Law Commission on the Work of ts Forty eighth Session, UN Doc. A/51/10 (1996) Thereinafter 1996 Draft Code]; ICTY Statute, supra note 29, Art. 5(c); ICTR Statute, supra note 30 , Art. 3(c); Rome Statute, supra note 31, Art. 7(1)(c).
} 
convicted Nazi commanders Fritz Sauckel and Baldur von Schirach of violating Article $6(c)$ for their roles in securing the forcible transfer into Germany of some five million foreigners-in the words of the Tribunal, 'under terrible conditions of cruelty and suffering'-to help relieve the wartime labour shortage. ${ }^{119}$ Although the Judgment alternatively deems the brutal working conditions to which the victims were subjected 'slave labour' and 'forced labour', it does not provide a legal definition for these concepts. ${ }^{120}$

Both the 1954 and 1996 ILC Draft Codes of Crimes Against the Peace and Security of Mankind list 'enslavement' as a predicate offence of crimes against humanity, but neither Code sets forth a definition of which acts constitute enslavement. ${ }^{121}$ The Commentary to the 1996 Draft Code, however, does provide an enlightening clarification: 'Enslavement means establishing or maintaining over persons a status of slavery, servitude or forced labour contrary to well-established and widely recognised standards of international law. ${ }^{122}$ The inclusion of servitude and forced labour comports with the enslavement formulation in the crimes-against-humanity analogue of the 1991 Draft Code. Article 21 of the 1991 Draft Code lists as a proscribed systematic or mass violation of human rights 'establishing or maintaining over persons a status of slavery, servitude or forced labour. ${ }^{123}$

The 1998 Rome Statute likewise incorporates a definition of 'enslavement' for purposes of crimes against humanity. Article $7(2)$ (c) seems at first glace to define that term in the same narrow fashion as the 1926 Slavery Convention: 'the exercise of any or all of the powers attaching to the right of ownership over a person'. ${ }^{124}$ The Article proceeds, however, to include in the definition of enslavement 'the exercise of such power in the course of trafficking in persons, in particular women and children', and the formulation in the Elements of Crimes expands the definition even further:

The perpetrator exercised any or all of the powers attaching to the right of ownership over a person, such as by purchasing, selling, lending or bartering such person or persons, or by imposing on

\footnotetext{
113 See Göring et al., International Military Tribunal, Judgment and Sentence, 1 October 1946 , in Trial of the Major War Criminals Before the International Military Tribunal, Nuremberg, 14 November $1945-1$ October 1946 (1947), Vol, 22, at 565-568.

$12 n$ See ibid.

1211954 Draft Code, supra note 118, Art. 2(11); 1996 Draft Code, supra note 118, Art, 18(d).

122 Report of the International Law Commission on the Work of Its Forty eighth Session, supra note 118 , at 98.

i23 1991 Draft Code, supra note 118, Art. 21. Recall that 'servitude' presumably includes the slavery-like practices of the 1956 Supplementary Slavery Convention. See note 80 and accompanying text, supra.

324 Rome Statute, supra note 31, Art. $7(2) / c)$. This part of the Rome Statute definition is a verbatim copy of the definition of slavery in the 1926 Slavery Convention. See 1926 Slavery Convention, supra note 47, Art. 1(1).
} 
them a similar deprivation of liberty. ... It is understood that such deprivation of liberty may, in some circumstances, include exacting forced labour or otherwise reducing a person to a servile status as defined in the Supplementary Convention on the Abolition of Slavery, the Slave Trade, and Institutions and Practices Similar to Slavery of 1956. It is also understood that the conduct described in this element includes trafficking in persons, in particular women and children. ${ }^{125}$

It would appear, then, that the scope of enslavement as a crime against humanity in the Rome Statute is broad indeed, including not only chattel slavery, but also trafficking in persons, the slavery-like practices of the 1956 Supplementary Slavery Convention (debt bondage, serfdom, etc.), and forced labour, presumably as defined in ILO Conventions No. 29 and 105.126

The following section of this article places the discussion of slavery and related activities into concrete context by evaluating Brazil's largely failed attempts at curbing the use of forced labour in the Amazon. Section 3 follows with an examination of whether such failure can give rise to state responsibility under the rather extensive regime of international obligations outlined above, and concludes with an examination of whether the individual perpetrators could be held criminally responsible under international law for placing persons in situations of forced labour, either for the commission of a freestanding international crime or a crime against humanity.

\section{The modest achievements of Brazil's anti-forced-labour campaign}

\subsection{Brazilian government action against forced labour}

As a result of an international shaming campaign orchestrated by the Pastoral Land Commission (CPT) in conjunction with several international NGO allies, ${ }^{127}$ the Brazilian government had no choice by 1993 but to openly

:25 ICC Elements of Crimes, Art. 7(1)(c), element 1 and n.11, reprinted in W. A. Schabas, An Introduction to the International Criminal Court $(2004), 279,284$.

326 The Rome Statute is also unique in specifically enumerating two other contemporary manifestations of slavery as crimes against humanity: sexual slavery and forced prostitution. See Rome Statute, supra note 31, Art. 7(1)(g).

127 The CPT's main international NGO allies have been Anti-Slavery International, which has sponsored annual trips by CPT leaders to testify before UN and European Union bodies, and the Center for Justice and International Law and Human Rights Watch, which have lent their financial support and legal expertise to the CPT in taking several emblematic cases of labour exploitation before the inter-American Commission on Human Rights. See 1. Cavallaro, 'Toward Fair Play: A Decade of Transformation and Resistance in International Human Rights Advocacy in Brazil', (2002) 3 Chicago Journal of International Law 481, at 484. See also text accompanying notes $177-183,226-237$, infra. 
acknowledge the continued existence of forced labour in its territory. ${ }^{128}$ Policy change came two years later with the presidential inauguration of Fernando Henrique Cardoso, ${ }^{129}$ who in June 1995 announced a series of pioneering antiforced-labour initiatives ostensibly designed to eliminate the practice by $2003 .{ }^{130}$ Despite some positive precedents, however, the Cardoso campaign failed to diminish the occurrence of forced labour, and when Luiz Inácio Lula da Silva succeeded to the presidency in January 2003, he immediately took on forced labour as one of his administration's top priorities. ${ }^{131}$ In March 2003 Lula promulgated an ambitious National Plan for the Eradication of Slave Labour ${ }^{132}$ designed to go far beyond Cardoso's efforts, setting 2006 as the target date for full eradication. ${ }^{133}$

Both administrations' plans have envisioned a multifaceted offensive against fazendeiros who make use of forced labour, including rigorous inspections of fazendas; tough criminal sanctions for subjecting workers to slavery-like conditions; high administrative fines and moral-damages judgments against labour-law violators; and other economic deterrents such as expropriation and suspension of development financing. The discussion that follows examines the major successes and failures of the two plans in tandem, as well as some of the reasons behind the failures.

\subsubsection{Federal labour inspections and freeing of workers}

The centrepiece of both presidents' reforms has been the creation and strengthening of the Mobile Group of Labour Inspection (Grupo Especial de Fiscalização Móvel), a centralised inspection agency within the Ministry of Labour. ${ }^{134}$ The Group, which has grown steadily in size and importance since 1995, consists of teams of labour inspectors that monitor fazendas nationwide

i28 Sutton, supra note 8, at 145 . The acknowledgement was made by former Labour Minister Walter Barelli at the annual ILO labour conference in Geneva. See ibid.

:29 Cardoso wrote his doctoral dissertation on the damaging social legacy of slavery in Brazil, subsequently published as F. H. Cardoso, Capitalismo e escravidão no Brasil meridional: $O$ negro na sociedade escravocrata do Rio Grande do Sul (1962, 2 d ed. 1977).

3 30 President Fernando Henrique Cardoso, Radio Address on Forced Labour (27 June 1995), in Ministério do Trabalho e Emprego (ed.), A experiência do Grupo Especial de Fiscalização Móvel 2002 (2002), 3 at 3. Cardoso utimately consolidated these meastures in 1996 under the National Program of Human Rights, which was revamped in 2002 . Ten of the 2002 Program's 518 human rigits proposals dealt with forced labour. See Ministerio da Justiça, Programa Nacional de Direitos Humanos I (2002), proposals 396-405.

131 In a speech at the ceremony launching the Plan, President Lula professed his administration's resolve: [Mluch more than simply creating a law, we are transfoming into the will of the state the eradication of slave labour in our country.' President Luiz inácio Lula da Silva, Address at the Launching of the National Plan for the Eradication of Slave Labour (11 March 2003) (author's translation) (transcript on file with author).

332 The Plan outlines 75 specific anti-forced-labour proposals. See generally Presidencia da República do Brasif, Plano Nacional para a Erradicação do Trabalho Escravo (2003).

133 'Nilmário Miranda lança campanha no auditório do Banco da Amazônia', Liberat (Belém), 26 November 2003.

13. The Mobile Group was created by Portarias MTE no. 549 and 550 of 14 June 1995. 
and raid-under the protection of Federal Police agents-any fazenda suspected of employing forced labour. If the Group finds forced labour, it confiscates weapons and directs the police to arrest gun wielding foremen, empreiteiros, gatos, and any other management-level personnel responsible for creating or perpetuating the forced-labour situation. It frees the workers and makes arrangements to return them to their places of origin. The Labour Ministry then puts pressure on the fazendeiro to pay the workers their back wages, under threat of legal action, and the fazendeiro remains subject to additional sanctions under federal labour and criminal legislation. ${ }^{135}$

The Mobile Group has freed forced labourers each year and has often managed to secure from the gatos and empreiteiros the payment of the workers' back wages. Nonetheless, although the number of freed peões increased significantly from 1995 (84) to 2003 (4,932, more than twice the 2002 figure and 85 percent of all workers liberated in all the previous years of the Group's existence combined ${ }^{136}$ ), the number decreased to 2,887 in $2004 .{ }^{137}$ For the first eight months of 2005 the number stood at just 3,025, despite the CPT's formal denunciation during the same period of 171 cases of forced labour involving some 5,500 workers. ${ }^{138}$ A 2004 LLO report attributed the diminution in part to a continued paucity of resources: while the Lula administration increased from four to six the number of inspection teams (amounting to an additional 150 labour inspectors) and provided more equipment to the Mobile Group (for example, 16 new four wheel drive vehicles), the Group's human and financial resources are still inadequate to effectively inspect many of the alleged forced-labour situations on hundreds of fazendas across the vast, remote, and inhospitable southern Amazon. ${ }^{139}$ Indeed, one labour inspector estimated in 2004 that the Group still reaches less than one third of the total of forced labourers in the country. ${ }^{140}$

\footnotetext{
135 Ministério da Justiça and Ministério do Trabatho e Emprego, $O$ combate ao trabalho forçado no Brasil (2002), 11.

136 H. Gomes Batista, 'Número de pessoas libertadas de trabalho escravo dobra em 2003', Valor Econômico, 17 December 2003.

137 J. Andrade, 'Il.O Praises the Way Brazills Dealing with Slave Labor', Agência Brasil (Brasilia), 12 May 2005.

138 R. Brasiliense, 'Mato Grosso lidera trabaho escravo', Liberal (Belém), 17 September 2005.

139 LO Committee of Experts on the Application of Conventions and Recommendations, Individual Observation Concerning Convention No. 29, Forced Labour, 1930 - Brazil (2005) thereinafter CEACR Reportl, available at http://www.ilo.org/ilolex/gbe/ceacr2003.htm. As recently as 30 March 2005, the interministerial commission in charge of the Mobile Group sent a letter to President Lula complaining that the per diems allocated to inspectors and their Federal Police protectors of 60 reais (about $€ 20$ ), were insufficient to cover food and lodging expenses during inspection trips. See Letter from National Commission for the Eradication of Slave Labour (CONATRAE) to President Luiz Inácio Lula da Silva (30 March 2005) (on file with author).

160 A. M. Dias, 'A casa-grande ataca', Carta Capital, 4 February 2004, 34, 36.
} 
Table: Number of Labourers Freed by the Mobile Group of Labour Inspection from January 1995 through August 2005

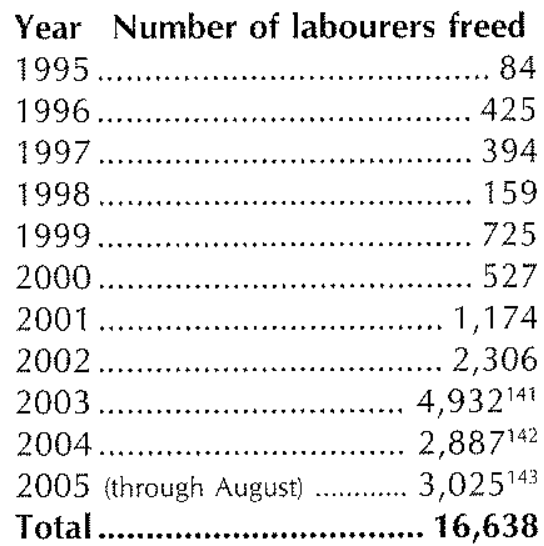

Brazilian Labour Ministry estimates put the total of freed workers from the beginning of the Mobile Group's existence in 1995 through August 2005 at approximately 16,600 (see Table, supra). Yet notwithstanding this seemingly laudable figure in relation to the estimated total of between 25,000 and 100,000 forced labourers in the country, ${ }^{144}$ most workers freed by the Mobile Group (an estimated 40 percent $t^{145}$ ) inevitably fall back into coercive labour relationships. The same fate befalls those discharged by the gato-with their debts 'forgiven' - when he no longer needs their services. Freed and discharged workers find their way back to small towns in the region and quickly spend what little money they have on lodging and sustenance; with insufficient resources to finance the trip home to Plauí or Maranhão and lacking other opportunities for employment, most peoes have little choice but to sign up with the next gato who passes through town. ${ }^{146}$ As the CPT's Ricardo Rezende explains, '[the peoes'] thinking is that "If I am hungry enough, I will run the risk and hope that this contractor is better than the other ones, because it's better to take that chance than let my family die of hunger." ${ }^{\prime \prime 47}$ Even more troublesome is the not uncommon posture of one worker critical of his liberation by the

\footnotetext{
:41 International Labour Organization, supra note 20, at 23 (figures from 1995 to 2003 ).

142 Andrade, supra note 137.

r43 Brasiliense, supra note 138.

i44 See notes 18-20 and accompanying text, supra.

14s CEACR Report, supra note 139.

$1 A 6$ Freed peöes seldom make it back to their states of origin, and end up permanenty in the southern Amazon, moving from fazenda to fazenda as job opportunities present themselves. This fact partially explains the high percentage of forced labourers recruited from towns in Para $(16 \%)$ vis à vis towns in Plaur $(22 \%)$ and Maranhäo (39\%). 'Escravos do século 21: O mapa da escravidão', O Dia Online, 16 November 2003.

147 L. Rohter, 'Brazil's Prized Exports Rely on Slaves and Scorched Land', N.Y. Times, 25 March 2002, A1 (translation in originaf).
} 
Mobile Group: 'If it wasn't for [the fazendeiros and the gatos], we'd all be on the street eating rubbish.' 148 The Group's limited reach, the high rate of recurrence, and the attitude of many of those freed suggest that simply liberating workers has done and will continue to do little to diminish the level of forced labour in the country. ${ }^{149}$

\subsubsection{Prosecutions and revamping of pertinent Penal Code provisions}

With more than 16,600 instances of forced labour discovered by the Mobile Group to date, one would expect to see many fazendeiros thrown in jail for having authorised or tolerated the use of forced labour on their holdings. But in spite of both administrations' repeated mentions of the need to impose serious criminal sanctions on fazendeiros to deter them from employing forced labour, only three fazendeiros were convicted of forced-labour crimes during the Cardoso period, one of these convictions was overturned on appeal, and no fazendeiro has been convicted under Lula's watch. Following raids on their respective Amazonian holdings, fazendeiros Silvio Caetano de Almeida and Antônio Barboso de Melo were convicted by federal judges of violating Article 149 of the Penal Code (reduction of another to a condition analogous to slavery), and sentenced to four and two years in jail, respectively; ${ }^{150}$ a federal judge convicted a third fazendeiro, Luiz Carlos Dal Bosco, of violating Article 149 in respect of the workers on his fazenda in the southern state of Santa Catarina. ${ }^{151}$ None of the three men has spent a single day behind bars. The judge in Barboso de Melo's case converted his sentence into the distribution of 30 food baskets to the needy. ${ }^{152}$ Caetano appealed his sentence-which the trial judge had converted into probation-and the Federal Regional Tribunal (Tribunal Regional Federal-TRF) for the First Region overturned the conviction. ${ }^{153}$ Dal Bosco, whose sentence the trial judge had commuted to community service and pecuniary damages, appealed as well, and the TRF for the Fourth Region upheld

148 A. Foster, 'Slave-Like Conditions Deep in the Amazon Reflect Brazil's Failure to Combat Poverty', Financial Post, 5 June 1996, 58 (translation in original).

is A generat sentiment of invincibility prevails among fazendeiros, evidenced by the significant rate of re raiding of the same fazendas: of the 117 Pará fazendas raided by the Mobile Group in 2002, at least 27 were subsequently re raided, and some fazendas have been re raided more than five times. H. des Roziers, Address at the Third Annual World Social Forum, Porto Alegre, Brazil (26 January 2003) (transcript on file with author).

5so Le Breton, supra note 3 , at 157 ค. $4,232$.

351 See TRF 4a Regiảo, Apelação Criminal no. 2001.04.01.045970-8, Juiz Relator Fábio Rosa (2002) (appeals court upholding trial court conviction) [hereinafter Dal Bosco Appeal].

152 Le Breton, supra note 3, at 157 n.4, 232.

153 TRF 1a Regiāo, Apelaçào Criminał no. 1998.01.00.064116-1, Juiz Relator Luciano Tolentino Amaral (1998) Thereinatter Caetano Appeal]. 
his conviction. ${ }^{154}$ Former Chief Federal Labour Judge Francisco Fausto has likened these punishments to a slap on the wrist for wealthy fazendeiros. ${ }^{155}$

A combination of factors-including jurisdictional disputes between federal and state judiciaries, the recalcitrance and inefficiency of both judiciaries, and pressures on judges, police, and labour inspectors from local powers-has hampered efforts to prosecute more fazendeiros. In fact, only a handful of gatos and small landowners have actually served real jail time for forced-labour crimes, and even these convicts seldom serve out the duration of their sentences. ${ }^{156}$ As explained in a 2001 ILO publication, '[t]he impunity enjoyed by those responsible, the slowness of judicial processes, and the lack of coordination among the governmental bodies end up protecting those responsible for exacting forced labour in Brazil and elsewhere. ${ }^{157}$

The criminal-law aspects of the fight against forced labour have enjoyed limited success in the legislative realm, however, with the December 2003 passage of a bill strengthening Penal Code Article 149 in several ways. ${ }^{158}$ First, it developed the enigmatic concept of a 'condition analogous to slavery' to include the forced submission of workers to an exhaustive work schedule or to degrading work conditions through the restriction of the workers' freedom of movement by whatever means, including through the imposition of a debt. Secondly, the amended provision criminalised several non physical coercive means of forcing a worker not to leave the locale, including patrolling by armed guards and the retention of documents or personal objects. Thirdly, the amendment provided for the imposition of a fine in addition to imprisonment, and it incorporated a one half increase in the punishment if the victim is a minor or the crime is committed on discriminatory grounds. ${ }^{159}$

is Dal Bosco Appeal, supra note 151. This 'split in the circuits' has to do with the respective competence of the federal and state judiciaries under the federal Constitution to hear criminal cases charging a violation of Article 149 . See otes $201-205$ and accompanying text, infra.

155 'Fausto: só confisco de terra acabará com trabalho escravo', Notícias do Tribunal Superior do Trabalho, 29 August 2003 .

is6 International Labour Organization, supra note 5, para. 81. For example, a judge ordered the early release of one particulariy notorious gato, the 70mear-old Antônio Avelino, because of his advanced age. Le Breton, supra note 3 , at $123,179,232$.

157 International Labour Organization, supra note 5, para. 81.

15B See 'Fausto destaca projetos contra trabalhos escravo e infantil', Notícias do Tribunal Superior do Trabalho, 20 November 2003.

$35 \%$ See Braz. Código Penal, Ast. 197. A second blil, passed by Congress in 1998 as Lei no. 9.777, amended Articles 203 and 207 of the Penal Code by criminalising such practices as luring workers from one state to another under fatse pretences, retaining documents in order to force someone to work, and obliging someone to buy merchandise from the fazenda store in order to build up a debt. See Braz. Código Penal, Arts. 203, 207. 
Nevertheless, the amendment as passed seems to have failed to satisfy the additional goals of anti-forced-labour advocates. A fourth proposed change would have increased Article 149's minimum sentencing threshold from two to four years; such an increase would have had a significant impact because, under Brazilian criminal law, a four-year minimum precludes the sentencing judge from suspending the sentence and substituting less harsh punishments, such as the donation of food baskets to the poor, probation, and community service (as has occurred in all three convictions under Article 149 to date) ${ }^{160}$ Yet while the Senate finally approved the bill with the higher sentencing threshold in 2002, it took another year for the Chamber of Deputies to follow suit by passing a diluted version that left the minimum sentence at two years. ${ }^{161}$ With President Lula's signature, this version of the bill became enshrined in Article 149, thus effectively ending the debate over the minimum sentencing threshold..$^{162}$ Indeed, the failure of the Chamber to sanction the Senate's raising of the minimum threshold seems to have removed many of the teeth that the reformed law would have had.

\section{2,1.3. Administrative sanctions for labour-law violations}

Former Chief Federal Labour Judge Fausto's harsh criticisms of the virtual inaction of his counterparts in the ordinary federal and state judiciaries (responsible for adjudicating crimes, as opposed to violations of the labour code) reflect a very different and less tolerant attitude on the part of many in the Brazilian labour judiciary and the federal Labour Public Ministry (Ministério Público do Trabalho). The Ministry has brought a great number of administrative proceedings against alleged forced-labour fazendas (more than 600 as of May $2005^{163}$ ), including several owned by high-profile state and federal politicians, and regional labour courts have found many of these fazendeiros responsible for labour-law violations, often ordering the payment of moral damages in addition to wage arrears.

Perhaps the two biggest fish found responsible thus far have been federal deputy Inocencio de Oliveira-made to pay 530,000 reais for maintaining 53 workers in slavery-like conditions on his Maranhão fazenda-and federal senator João Ribeiro, whose damages amounted to 760,000 reais for 38 workers on his Pará fazenda. ${ }^{164}$ Ribeiro's judgment was the second largest ever awarded in a forced-labour case. ${ }^{165}$ Federal labour judge Jorge Vieira, who was forced to

\footnotetext{
160 G. Doca, 'Lei que pune trabatho escravo será mais dura', Globo (Rio de Janeiro), 30 October 2003.

361 Diário do Senado Federal, 25 November 2003, available at http:/www.senado.gov.br.

$\$ 62$ Trabalho escravo: Fáusto elogia alteração no Codigo Penal', Notícias do Tribunal Superior do Trabalho, 15 December 2003.

863 International Labour Organization, supra note 20, para. 91.

164 L. Sakamoto, 'Senador condenado por trabalho escravo', Carta Maior, 23 February 2005.

$i 65$ lbid.
} 
abandon his Pará labour court during several months of 2003 and 2004 after receiving death threats, ${ }^{166}$ has been the most active in holding forced-labour fazendeiros responsible, ${ }^{16 \%}$ overseeing the largest settlement ( 1.35 million reais in August 2004) and imposing the first (in 2002) and largest ( 3 million reais in May 2005) damages awards in relation to forced labour. ${ }^{168}$

\subsubsection{Other measures}

In 1995 federal deputies introduced a proposed amendment to Article 243 of the federal Constitution to allow for the uncompensated expropriation of forced-labour fazendas; the expropriated lands would be consigned to the agrarian reform and reserved for the persons who had been forced to work on them. ${ }^{169}$ Former Chief Labour Judge Fausto and former Human Rights Secretary Nilmário Miranda have argued vehemently in favour of the proposal, known as Proposta de Emenda Constitucional (PEC) no. 438/01 in its current form, stressing that the only truly effective way to counterbalance the economic incentive to use forced labour is with an even greater economic disincentive. ${ }^{170}$

Nonetheless, despite a decade on the table, passage by the Senate in 2002, and reiterated calls-including from President Lula himself-for the proposal's passage in the wake of the massacre of three Mobile Group inspectors in January 2004, ${ }^{171}$ as of September 2005 PEC no. 438/01 still languished before the Chamber of Deputies, ${ }^{172}$ where resistance from a small but powerful band of deputies from within the fazendeiro sphere of influence has managed to keep the proposal from even coming to a vote. ${ }^{173}$ Prospects for the proposal's

166 'Fausto cobra proteção da Polícia Federal a juiz ameaçado no Pará, Notícias do Tribunal Superior do Trabalho, 1 October 2003.

16 Des Roziers, supra note 149.

768 L. Sakamoto, 'No dia da aboliçăo, sai maior condenaçăo por trabatho escravo no país', Carta Maior, 13 May 2005. The Lula administration can claim additional success in the November 2003 promulgation of a so-called 'dirty list' of persons and companies which exploit forced labour. The Labour Ministry forwards the list-which in September 2005 contained 188 names-every six months to state financial institutions, urging them to suspend the impugned entities' credit and development financing. See Portaria no. 1.150 de 18 de novembro de 2003 (do Ministério de Fstado da Integração Nacional). See also 'OIT, Ethos e Repórter Brasil lançam sistema de busca da lista suja-agência', Carta Maior, 12 September 2005.

169 L. Sakamoto, 'Ainda há fazendas que 'contratam' pessoas sem nenhum direito', in Ministério do Trabalko e Emprego, supra note 130, at 84, 89. Article 243 of the Constitution currently includes only fazendas on which psychotropic plants are found. See Braz. Constitution, Art. 243.

170 D. Weber, 'OIT elogia Brasil no combate do trabalho escravo', Globo (Rio de Janeiro), 12 May 2005. See also R. Gomide, 'Relatótio complica Picciani', Dia (Rio de Janeiro), 22 luly 2003 . Indeed, the loss of a. fazenda would likely bring much graver economic consequences than even a civil-damages judgment rendered by Judge Vieira; for example, the Lima Araújo fazendas, for which Vieira recently imposed the record-high judgment of 3 million reas, have a combined value of more than 212 million reais. Sakamolo, supra note 168.

i7) 1. Braga, 'Lula decide apressar projeto contra escravidăo', Globo (Rio de Janeiro), 11 February 2004.

172. Brasiliense, supra note 138.

173 P. Audi, 'Trabatho escravo: avanços e desafios', Correio Braziliense (Brasilia), 19 May 2005. 
passage in the near future look grim, moreover, with influential congressmen such as former Chamber President Severino Cavalcanti promising to 'throw [the proposal] in the trash."174 This opposition group, which has also been responsible for eviscerating Penal Code Article $149^{175}$ and perpetuating legislative logjams in respect of other proposed anti-forced-labour laws, claims that uncompensated expropriation would jeopardise private property rights, free initiative, and free competition. ${ }^{1 \% 6}$

Potentially even more troublesome than these enduring obstacles, however, is the current administration's refusal to accept responsibility for failing to prevent human rights abuses committed in Brazil, notwithstanding repeated proclamations to the contrary. One final legislative enactment that deserves mention is the law conceding 52,000 reais to José Pereira ${ }^{177}$-a rural worker whom fazenda thugs shot and seriously injured in 1989 after he tried to escape from a forced-labour fazenda-pursuant to a settlement reached with the CPT and its international NGO allies and approved by the Inter-American Commission on Human Rights. ${ }^{178}$ In spite of former Human Rights Secretary Miranda's public boasts that the Pereira settlement symbolises the government's reconciliatory attitude, the wording of the law as passed reflects a rather different position. ${ }^{179}$ While the bill contains the language arising out of the responsibility assumed by the Union under international human rights treaties ${ }^{\prime}{ }^{180}$ no such language appears in the law as passed, which contains the following disclaimer: 'The payment of damages ... exempts the Union from providing any other compensation to the beneficiary. ${ }^{181}$

Moreover, in this instance the bill's watering down came not as a result of opposition from fazendeiro allies in Congress, but at the Lula administration's own prompting. In a brief to Congress opposing the bill's absoluteness, executivebranch lawyers argued that, since Brazil did not adhere to the American Convention on Human Rights until 1992 and did not submit to the jurisdiction of the Inter-American Court until $1998,{ }^{182}$ the Court lacked the competence to

\footnotetext{
17* R. Boechat, "Jà era: PEC contra o trabalho escravo "no lixo" " Jornal do Brasil (Rio de janeiro\}, 22 Feluruary 2005 (author's translation).

:75 See text accompanying notes $160-162$, supra.

v7 Gomide, supra note 21.

177 Lei no. 10.706 de 30 de julho de 2003.

178 'Governo indeniza vitima de trabalho escravo', Folha de São Paulo, 19 September 2003. The Inter-American Commission's opinion in the case of Pereira v. Brazil is discussed in Section 3.1, infra. See text accompanying notes $227-237$.

179 Note also that 52,000 reais- the quantity Pereira received from the Brazilian government some 14 years after his having been shot through the hand and head by fazenda gunmen-equals about $€ 17,000$.

\{80 Minuta de Projeto de Lei concedendo indenizaça a josé Pereira (February 2003) (author's transiation) (on fle with author).

:a1 Lei no. 10.706, stipra note 178, Art. 1, parágrafo único (author's translation).

1dz See Decreto Legislativo no. 89 de 3 de dezembro de 1998 (Brazil recognises the jurisdiction of the inter-American Court of Human Rights); see also Decreto no. 678 de 6 de novembro de 1992 (Brazil adheres to the American Convention on Human Rights).
} 
hear a case arising out of a 1989 incident. They claimed additionally that Brazil's agreement to compensate Pereira would not set a precedent, that state authorities had indeed taken reasonable measures to investigate the incident and prosecute those responsible, and that the settlement would not establish the state's liability for this or any other human rights abuse committed by private individuals. ${ }^{183}$

The administration's hesitant reaction to recent demands for reparations for military-regime atrocities similarly evinces an aversion to full assumption of responsibility. ${ }^{184}$

\subsection{Some reasons behind the government's lacklustre accomplishments}

Brazil's size makes it extremely difficult for the central state to deal effectively with the country's multiplicity of problems, particularly in the seemingly limitless expanses of the infrastructure poor and sparsely populated Amazon. In the north of the country, fazendeiro families bring in the majority of the region's income and wield a great deal of influence through close financial, personal, and even family connections with the political class. ${ }^{185}$ Such ties have contributed significantly to local authorities' unwillingness to cooperate with federal labour inspectors and other 'meddling' officials from Brasilia. ${ }^{186}$

Where fazendeiros cannot fill government positions with those under their direct control, they buy off public agents to secure universal complicity. ${ }^{187}$ State police, prosecutors, and judges-often along with their federal counterparts-tend to exhibit strong loyalty to local power elites. In the words of Paulo Sérgio Pinheiro, Human Rights Secretary under President Cardoso, '[p]olice and other institutions of the criminal justice system tend to act as border guards protecting the elites from the poor. Throughout the country, impunity is virtually assured for those who commit offences against victims considered "undesirable" or "subhuman"."188 The poorly paid state police manifest the most overt allegiance to the fazendeiros and generally see no

183 D. C. Figueira (Advogada da Uniāo), Nota SA) no. 219/03 - DCF (25 February 2003), at 3 (on file with author).

184 See L. Rohter, 'Long After Guerrilla War, Survivors Demand Justice from Brazil's Government', N.Y. Times, 28 March 2004, A8. The administration's July 2005 downgrading of the national Human Rights Secretariat from a cabinet-level ministry to a sub secretariat subordinated to the Ministry of fustice has additionaily given rise to strarp criticism from those who accuse President Lula of having abandoned his human rights agsenda. See B. Barbosa, 'Entidades protestam contra mudança de status de Secretaria', Carta Maior, 15 July 2005.

385 5. P. Mainwaring, Rethinking Party Systems in the Third Wave of Democratization: The Case of Brazil (1999), 335.

186 Human Rights Watch, supra note 5, at 7.

197 Le Breton, supra note 3, at 227.

198 P. S. Pinheiro, 'Democratic Governance, Violence, and the (Un)Rule of Law', Daedalus, Spring 2000, 119, at 126. 
need to intervene in the local labour landscape, except to apprehend fugitive peões and return them to the fazenda from which they escaped. ${ }^{189}$

Fazendeiros use a combination of assassination and threats of assassination to incapacitate all remaining poles of potential resistance. Southern Pará has a national reputation for violence; death threats of judges such as Jorge Vieira ${ }^{190}$ and murders of lawyers, priests, union leaders, and human rights activists occur with alarming frequency. ${ }^{191}$ Fazendeiros and their loyalists have also set their sights on members of the Mobile Group: in January 2004, three federal labour inspectors and their driver were gunned down while on a mission to inspect fazendas near the city of Unai in north-western Minas Gerais. ${ }^{192}$ Former Unaí mayor Norberto Mânica, Brazil's largest bean grower whose fazendas had been the target of Mobile Group raids, was indicted in relation to the massacre after the captured gunmen confessed that he had paid them US $\$ 17,000$ to kill the inspectors. ${ }^{193}$ Brazil's highest court, the Supreme Federal Tribunal (Supremo Tribunal Federal), provisionally released Mânica on 31 August 2005 pending the commencement of proceedings against him. ${ }^{194}$

Fearful that fazendeiro influence taints the professionalism of the state judiciary in cases implicating local fazendas, anti-forced-labour campaigners have repeatedly emphasised the desirability-and indeed the obligation-of federal adjudication of forced-labour cases. Article 109 of the Brazilian Constitution gives the federal judiciary competence to adjudge 'crimes against the organisation of labour'. ${ }^{195}$ Articles 197, 203, and 207-three of the four main Penal Code provisions pertaining to forced labour ${ }^{196}$-are in the section of the Penal Code (which predates the Constitution by nearly five decades) entitled 'Of Crimes Against the Organisation of Labour'. And while Article 149 (proscribing subjecting someone to slavery-like conditions) is in another section, several Brazilian jurists have contended that a violation of Article 149, since it necessarily involves labour exploitation, constitutes a crime against the organisation of labour. Thus, these jurists convincingly argue, all four antiforced-labour provisions fall squarely under federal jurisdiction. ${ }^{197}$

:89 Le Breton, supra note 3, at 76 .

i90 See note 166 and accompanying lext, supra.

191 R. Marques, 'Padre Ricardo, um sobrevivente, reaparece em ato por Tim Lopes', Globo, 4 August 2002. CPT leaders Ricardo Rezende and Henri des Roziers have escaped numerous attempts on their lives, and CPT lawyer Pauto Fonteles was killed in 1987 after denouncing unlawful fazenda practices. Le Breton, supra note 3 , at 68 .

392 'Fiscais do trabahtho sảo assassinados no noroeste de Minas', CBN Minas, 28 January 2004.

193 'Mato Grosso é o primeiro em trabalho escravo', Folha do Estado (Cuiabá), 14 September 2005 . See also Davidson, supra note 19.

194 'STF concede hábeas corpus a acusado do crime de Unai', Folha Online, 31 August 2005.

:95 Braz. Constitution, Art. 109, V1.

:96 The four main anti-forced-labour articles in the Penal Code are Articles 149, 197, 203, and 207.

i97 See F. D. de Castro e Costa, O combate ao trabalho forçado no Brasil: Aspectos jurídicos (2002), 9. 
Notwithstanding Article $109^{\prime}$ s apparent mandate, however, federal judges have frequently declared themselves incompetent to hear forced-labour cases, and have relegated them to state courts. ${ }^{198}$ This tendency to relegate has dealt a substantial blow to the anti-forced-labour campaign because, although the federal judiciary is slow and overworked, it is significantly more efficient and less corrupt than the state judiciaries. ${ }^{199}$ Former Human Rights Secretary Pinheiro suggests that such relegation reflects the traditional judicial mindset:

Access to justice in Brazil, especially for the poor, has always been extremely precarious. Historically, the judiciary has not been perceived as a body that protects the rights of the underprivileged classes, but rather as an institution responsible for the criminalization and repression of these classes. ${ }^{200}$

The federal judges who have relegated forced-labour cases to the state judiciary typically cite as authority a 1970 s opinion from the extinct Federal Appeals Tribunal (Tribunal Federal de Recursos) which, although it classified 'crimes against the organisation of labour' as federal offences, sanctioned the remittal of 'crimes against specific workers' to state judiciaries. ${ }^{201}$ The TRF for the First Region-whose jurisdiction covers the entire central and northern regions of Brazil-affirmed this position in overturning the conviction of fazendeiro Silvio Caetano de Almeida, holding that the federal courts lack the competence to hear forced-labour cases. ${ }^{202}$ By direct contrast, the TRF for the Fourth Region-covering the three southernmost states of Brazil-declared the constitutional competence of the federal judiciary to hear cases charging a violation of Article 149, and correspondingly upheld the conviction of fazendeiro Luiz Carlos Dal Bosco. ${ }^{203}$ The federal Public Ministry has appealed the Caetano judgment to the Supreme Federal Tribunal. ${ }^{204}$ The Tribunal's judgment, the first ever on forced labour from Brazil's highest court, was still pending as of mid-October 2005.205

198 International Labour Organization, supra note 20, para. 89.

:9s See H. des Roziers, 'Limites do governo brasileiro na luta contra o trabalho escravo', in Trabalho escravo no Brasil contemporaneo, supra note 1 , at $209,212-213$.

200 Pinheiro, supra note 188 , at 130.

20: See, e.g., Hábeas Corpus no. 92.01.04616-2-PA (Parecer 511-ME) (1992); see also Decisão da Dra. Ednamar Silva Ramos, Juiza Federal Substituta, Palmas, 10, 19 December 2001, cited in Le Breton, 5upra note 3, at 232.

202 Caetano Appeal, supra note 153.

203 Dal Bosco Appeal, supra note 151.

204 Supremo Tribunal Federal, Recurso Extraordinária no. 398041, Relator Ministro Joaquim Barbosa (2005).

205 Seehttp//Www.stf.gov.br/processos/processo.asp?PROCESSO $=398041 \& C L A S S E=R E \& O R I G E M=A P \& R E C U R S O=$ 0\&TIP JULGAMENTO $=\mathrm{M}$ (last visited 14 October 2005). A preliminary vote on 3 March 2005 favoured recognising the competence of the federal judiciary by four votes to two. See 'Justiça Federal sai em vantagem no STF', available at http:/ $/$ ww.ajufe.org.br/index.php?a $=04$ informativo mostra.php\&ID_MATER)A $=1308$ (Associaça dos fulzes Federais do Brasit website). 
Finally, as suggested above in regard to the proposed constitutional amendment providing for uncompensated expropriation of forced-labour fazendas, ${ }^{206}$ an exceedingly large amount of national policymaking reflects the interests of the traditional rural power base in the north of Brazil. Many northern congressmen are fazendeiros themselves, and most others come from within the fazendeiro sphere of influence. ${ }^{207}$ This fazendeiro faction, which enjoys substantial heft due in part to representational malapportionment in both the Senate and the Chamber of Deputies, ${ }^{208}$ has put up strong and effective opposition to efforts by Presidents Cardoso and Lula to stiffen sanctions against rural labour exploiters. ${ }^{209}$

In order to combat forced labour effectively the government must, at a minimum, find the workers; free them; and arrest, prosecute, imprison, and levy fines against those responsible. It must furthermore create laws that address those offences typical to the forced-labour context and that target those for whom the anticipated deterrent effect will have the most impact. Particularly in the vast and sparse Amazon, these tasks require exceptional cooperation and zeal-mor at the very least acquiescence-on the part of a multiplicity of government actors, including the president and his administration, federal legislators, the federal judiciary, labour inspectors, the police, and local officials. Forced labour continues to thrive in Brazil because no leader has yet been able to secure all the components of this manifold alliance. The following section of this article discusses the international legal consequences of the continued existence of Amazonian forced labour, both in terms of the responsibility of Brazil and that of the individual perpetrators of the practice.

\section{The international legal consequences of the continued existence of forced labour in Brazil}

\subsection{The Brazilian state's responsibility for forced labour}

In international law the overwhelming majority of obligations and the burden of compliance with them are placed upon states, as opposed to individuals, corporations, international organisations, or other non state groups. Brazil has ratified all the anti-slavery and anti-forced-labour conventions

\footnotetext{
206 See notes $169-176$ and accompanying text, supra.

207 Gomide, supra note 176.

${ }_{206}$ While Brazil's three senators per state is not unlike the upper parliamentary chambers of many countries, even the population-based Chamber of Deputies exhibits substantial malapportionment. Article 45 of the Constitution mandates that no state should have fewer than eight or greater than 70 deputies. As a result, the North as a whole has nearly twice as many deputies as it would have in the absence of the 8-70 floor and ceiling. Braz. Constitution, Art. $45 \$ 10$. See also R. Snyder and D. Samuels, 'Devaluing the Vote in Latin America', Journal of Democracy, January 2001, 146, at 151.

209 See Des Roziers, suprat note 199 , at 211.
} 
discussed in Section 1, as well as the ICCPR and the ACHR, ${ }^{210}$ and it thus bears a conventional and customary obligation not to engage in slavery, the slave trade, slavery-related practices, and 'illegal' forms of forced labour (for example, forced labour not pursuant to military service, not in response to an emergency, etc.). Because states are juridical abstractions which necessarily act through organs or agents, the ILC's Draft Articles on State Responsibility set forth a number of conditions under which the actions of individuals or entities in violation of an international obligation binding upon a state can be attributed to that state. By operation of the rules of attribution, the entities that can engage the Brazilian state's responsibility for contravening the anti-slavery and antiforced-labour norms include agents of any branch of government, such as legislators, police officers, local mayors, and individual judges. ${ }^{211}$

Nevertheless, although a great number of human rights depredations throughout the world are committed by persons acting in a public capacity pursuant to government policy, slavery-related activities, like terrorism and hostage-taking, are most frequently carried out by private actors not acting under any colour of state authority and whose actions are never subsequently ratified by the state. ${ }^{212}$ Such is certainly the case with Amazonian forced labour: the persons responsible for perpetuating these human rights atrocities are private landowners and their managementlevel employees, and while many fazendeiros also hold government posts (for instance, as mayors or legislators), it would be difficult to argue that actions taken by such persons in a purely private capacity can potentially bind the Brazllian state. ${ }^{213}$

Yet in spite of the ostensibly negative character of civil and political human rights norms, international tribunals, human rights bodies, and scholars universally recognise that in many circumstances a state has positive obligations to ensure that individuals within its jurisdiction do not violate rules of international law, including those enshrined in conventional and customary human rights law, and that those who do commit such violations are adequately punished.

The seminal case in this regard is the Janes claim, in which the US Mexico General Claims Commission held the Mexican state responsible under

\footnotetext{
210 Brazil ratified the ICCPR in January 1992 and the ACHR in fuly 1992. See http://www.ohchrorg/english/ countries/ratification/4.htm (ICCPR ratifications); http:/www.oas.org/ juridico/english/Sigs/b-32.html (ACHR ratifications).

21 Draft Articles, supra note 94 , Arts. $1-2,4$.

232 See M. C. Bassiouni, 'The Proscribing Function of International Criminal Law in the Processes of International Protection of Human Rights', (1982) 9 Yale journal of World Public Order 193, at 194 [hereinafter Bassiouni $1982]$.

233 See Draft Articles, supra note 94, Art. 7 \{even if exceeding authority or contravening instructions, a government agent can only bind the state if acting in his capacity as an organ of the state).
} 
international law for its failure-via the negligence and incompetence of its police, prosecutorial, and judicial authorities-to take adequate steps to pursue and punish a private citizen suspected of having murdered a US national..$^{14}$ In the same vein, the International Court of Justice in the Tehran Hostages case held the Iranian state responsible for breaching its obligation under the Vienna Conventions on Diplomatic and Consular Relations and a bilateral treaty of amity to protect the US embassy and consulates, basing its finding in part on the Khomeini government's failure to take measures to control the militants who overran the embassy and seized its staff as hostages. ${ }^{215}$ Likewise, the European Court of Human Rights has held that the ECHR imposes a duty on states parties to prevent and punish private conduct that violates certain rights protected by the Convention, including the right to life; the Court has consistently held that the Convention's Article 1 duty to secure the rights and freedoms enshrined in the Convention imposes an obligation on the public authorities to take preventive operational measures to protect an individual whose life is at risk from the criminal acts of another individual.216

The landmark judgment on positive obligations in the realm of international human rights law came from the inter-American Court of Human Rights in 1988. In Velasquez Rodriguez v. Honduras, the Court held that ACHR Article 1's obligation to ensure the full exercise of the Convention's rights and freedoms imposes on the state a duty to 'prevent, investigate and punish any violation recognized by the Convention and, moreover, if possible attempt to restore the rights violated and provide compensation as warranted for damages resulting from the violation. ${ }^{217}$ Hence, a human rights violation which is not directly imputable to the state can still trigger state responsibility because of the state's lack of 'due diligence' in preventing the violation or responding to it adequately. ${ }^{218}$ This duty to act includes not only reasonable prevention and investigation of alleged incidents, but also the establishment of a system of criminal law under which the offenders may be prosecuted and punished adequately. ${ }^{219}$

\footnotetext{
214 Janes claim (US v. Mexico), (1926) 4 RIAA 82.

21.5 United States Diplomatic and Consular Staff in Tehran (US v. Iran), Judgment of 24 May 1980, [1980] IC] Rep. 3, paras. 67, 69.

216 ECHR, supra note 39, Art. 1; Osman v. United Kingdom, [1998] 29 EHRR 245, para. 115; Güleç v. Turkey, [1998] 28 EHRR 121, para. 77; Kelly et al, v. United Kingdom, [2001] ECHR 240, para. 94; Mastromatteo v. Italy, [2002] ECHR 689, para. 67.

237 Velasquez Rodriguez v. Honduras, inter-Am. Ct. H.R. (Ser, C) No. 4, \{1988), para. 166.

2.8 lbid, para. 172.

219 tbid., para. 166.
} 
A responsibility to prevent non state entities and private individuals from subjecting others to slavery, the slave trade, slavery-like practices, and forced labour, as well as a duty to investigate alleged transgressions, could arise from the duty to ensure and protect human rights which appears in all the general human rights instruments discussed above. ${ }^{220}$ Moreover, many provisions in the anti-slavery and anti-forced-labour conventions also impose specific obligations on states parties to prevent treaty violations by state and private actors alike, and to hold the perpetrators individually accountable. Article 1 of the 1956 Supplementary Slavery Convention provides a forceful example, obligating states parties 'to bring about ... the complete abolition' of all slaverylike practices, including imposing criminal penalties for such conduct; ${ }^{221}$ Article 25 of ILO Convention No. 29 commands state parties to make forced or compulsory labour as defined under the Convention punishable as a penal offence, and to ensure that penalties 'are really adequate and strictly enforced. ${ }^{222}$ Furthermore, the perpetration of the contemporary manifestations of slavery could engage state responsibility under several other human rights provisions which impose positive obligations, including the right to life; ${ }^{223}$ the right to freedom from torture, inhuman, or degrading treatment or punishment, ${ }^{224}$ and the right to liberty and security. ${ }^{22.5}$

Under the rubric of positive obligations, then, the conduct of many of the organs of the Brazilian state and federal governments in respect of Amazonian forced labour may indeed give rise to state responsibility. The InterAmerican Commission made such a finding in the only inter-American decision thus far to deal with Brazilian forced labour, Pereira v. Brazil, mentioned above in Section 2.226 When José Pereira (then aged 17) and a co worker known as 'Parana' attempted to flee from a fazenda in southern Pará in 1989, fazenda thugs pursued the men, gunned them down, and left them for dead. Pereira

220 ECHR, supra note 39, Art. 1; ACHR, supra note 76, Art. 1; ICCPR, supra note 75, Art. 2.

1956 Supplementary Slavery Convention, supra note 56, Arts. 1, 3,6.

[LO Convention No. 29, supra note 66, Art, 25. See also, e.g., ibid., Art. 4(1)-(2) (obliging states parties not to permit forced labour for the benefit of private individuals); HO Convention No. 105, supra note 32, Art. 2 (imposing duty on states parties to take 'effective measures' to secure the immediate and complete abolition of forced or compulsory labour as defined under the Convention); 1926 Siavery Convention, supra note 47, Art. 2(a) (obliging states '[t]o prevent and suppress the slave trade'). ECHR, supra note 39, Art. 2; ACHR, supra note 76, Art. 4; ICCPR, supra note 75, Art. 6. See atso Osman v. United Kingdom, supra note 216, paras. 115-116; Villagrán Morales et al. $v$. Guatemala, Inter-Am. Ct. H.R. (Ser. C) No. 63, para. 54 (2001) (astirming Guatemala's positive obligation to create conditions so that violations of right to life in ACHR Article 4 do not occur).

224 ECHR, supra note 39, Art. 3; ACHR, supra note 76, Art. 5; ICCPR, supra note 75, Art. 7. See also Z. el at. v. United Kingdom, [2001] 34 EHRR 3, para. 73 /'States [must] take measures designed to ensure that individuals within their jurisdiction are not subjected to torture or inhuman or degrading treatment, including such ill treatment administered by private individuals 7 . ECHR, supra note 39, Art. 5; ACHR, supra note 76, Art. 7; ICCPR, supra note 75, Art. 9. See afso Nielsen v. Denmark, [1988] 144 ECHR (Ser. A), para. 64.

226 See texi accompanying notes $177-183$, supra. 
miraculously survived to tell his story to the CPT, which then reported what had happened to the appropriate authorities. Despite their knowledge of forcedlabour conditions on this particular fazenda through scores of complaints that had come in since at least 1987, the state and federal authorities, including the Federal Police, proceeded very sluggishly with their investigation. In the meantime the body of Parana disappeared along with other evidence implicating the perpetrators, and nine years after the incident, when the Commission rendered its decision, the only concrete judicial action that had taken place was the dropping of charges against a fazenda administrator due to the lapsing of the time limit for beginning criminal proceedings. ${ }^{227}$

Invoking the Velasquez Rodriguez doctrine of due diligence, the Commission opined that the Brazilian state was responsible for violating several provisions of the American Declaration of Rights and Duties of Man, the ACHR as regards actions and omissions from Brazil's 1992 ratification of the Convention onwards, and obligations under the anti-slavery and anti-forced labour conventions to prosecute and punish private violations. ${ }^{228}$

The violated Declaration and Convention rights included the right to life, liberty, and security; ${ }^{229}$ the right to free movement; $; 30$ the right to preservation of health; ${ }^{231}$ the right to work under proper conditions and with proper remuneration; ${ }^{232}$ the right to leisure and advantageous use of free time, ${ }_{i}^{233}$ and the right to an effective judicial remedy to ensure respect for legal rights. ${ }^{234}$ One state organ that the Commission determined to have engaged Brazil's responsibility was the national Congress, for its failure to organise Brazil's legislative apparatus to permit state and federal authorities to effectively prevent and punish situations of work oppression. ${ }^{235}$ Other impugned authorities included the state and federal courts for violating the obligation to provide Pereira, Paraná, and their fellow fazenda workers with an adequate judicial remedy, and the state and federal police for falling to undertake a proper investigation. ${ }^{236}$ As discussed in Section 2, the Lula administration ultimately settled the Pereira case before proceedings began in the Inter-American Court. ${ }^{237}$

\footnotetext{
227 Pereira v. Brazil, Case 17,289, Inter-Am. C.H.R., OEA/Ser/LN/1.102, doc. 28 (report no. 21/99) (1999), paras. $59-83$.

228 lbid., paras. 84-87.

22: 1948 American Declaration of Rights and Duties of Man, 2 May 1948, Art. 1, OAS Off. Rec. OEA/Ser.UN/ II.23/Doc.21/Rev.6 (1948).

230 loid., Art. VIll.

231 loid., Art. Xl.

232 Ibid., Aft, XIV.

23.3 lbid, Art. XV.

234 lbid., Art. XVIll; ACHR, supra note 76, Art. 25.

235 Pereira v. Brazil, supra note 227, para. 93.

236 lbid., paras. 102-04, 110-12.

237 See Lei no. 10.706, supra note 178. See also notes $177-183$ and accompanying text, supra.
} 
Although the Brazilian authorities' response to the forced-labour phenomenon has improved enormously since the 1989 attack on Pereira and even since the Commission's 1999 decision, many of the violations cited by the Commission persist today, including legislative and constitutional confusion as to which entity - the federal or state judiciary - is responsible for adjudicating charges of reducing someone to a condition analogous to slavery, insufficient investigations of forced-labour situations and prosecutions of fazendeiros, and the lack of a constitutional provision allowing for uncompensated expropriation. ${ }^{238}$

Indeed, Brazil still appears far from satisfying its extensive legal obligations as spelled out by the Commission, and many of the root causes behind these enduring stumbling blocks-such as de facto fazendeiro control over local mayors, police, and judicial authorities and the northern bias in Congress-seem unlikely to go away anytime soon regardless of condemnation by the Inter-American Commission and Court. The Brazilian state is simply incapable at this stage of its development to abide by all of its stringent obligations under international law in respect of forced labour, especially taking into consideration the abundance of arguably more pressing human rights crises elsewhere in the country and the extreme difficulty of monitoring and policing such remote and transitory activities. Subsection 3.2 of this article examines whether the individual perpetrators of forced labour could be held criminally responsible under international law for their acts, and whether individual responsibility could present a viable alternative to state responsibility.

\subsection{Individual international criminal responsibility for Brazilian forced labour}

\subsubsection{Prosecution in national courts}

Section 1 of this article examined certain provisions in the anti-slavery and anti-forced-labour conventions, such as the duty to criminalise the conduct under national law and punish offenders, that provide strong evidence that slavery, the slave trade, slavery-like practices, and illegal forced labour constitute freestanding international crimes. ${ }^{239}$ As mentioned in that section, notwithstanding the tendency of commentators on the Brazilian situationincluding many scholars, the ILO, ${ }^{240}$ and even the government--to employ the terms 'slave labour,' 'escravidão', and 'escravatura', under international law the crime about which they are writing does not fit into the normative paradigm of slavery per se, nor does it constitute debt bondage in terms of the 1956 Supplementary Slavery Convention. The proscription of slavery in the 1926

\footnotetext{
238 See notes $150-162,169-176,195-205$ and accompanying text, supra.

239 See notes 105-115 and accompanying text, supta.

240 See, e.g., International Labour Organization, supra note 20 , at 74 .
} 
Slavery Convention contemplates legal ownership of the victim; ${ }^{241}$ Brazilian law has prohibited one person from legally owning another since the abolition of slavery in $1888 .^{242}$ The 1956 Convention's definition of debt bondage, moreover, requires a voluntary pledge by the debtor of his services as security for an existing debt; ${ }^{243}$ by contrast, Brazilian peões' debt arises only after they have begun work and are obliged to purchase food, clothing, and equipment on credit.

The activities do, however, seem to fit squarely into the definition of illegal forced labour under Convention No. 29. The Convention considers labour 'forced' when it occurs under the menace of any penalty and the worker has not offered himself voluntarily, ${ }^{244}$ and the European Court of Human Rights has opined that involuntariness can come about not only through physical coercion, but also through psychological coercion. ${ }^{245}$ While the peoses' initial decision to work may be voluntary, it becomes effectively involuntary when, to their surprise, they must work to liquidate a debt which began to accrue during the long journey out to the fazenda when the gato paid for their meals and lodging. The extreme isolation of most fazendas, the psychological trauma of skipping out on a debt, and the possibility of meeting the same fate as José Pereira and his friend 'Parana' keep most peôes from even considering escape. ${ }^{246}$ Additionally, none of the forced-labour norm's many exemptions apply to the Amazonian context: the work is not exacted pursuant to an emergency, for example, and does not form part of civic obligations, ${ }^{247}$ and forced labour non public purposes is prohibited in any case..$^{248}$

National criminal jurisdictions play the central role in the enforcement of international criminal law, acting on behalf of the international community to suppress criminal conduct which falls outside the very restricted scope of the international and internationalised criminal tribunals. Two powerful provisions of the anti-slavery conventions arguably permit the prosecution of Amazonian forced labour in foreign states' courts: first, when read in conjunction, Articles 5 and 6 of the 1926 Convention impose on states a duty to criminalise and prosecute any private use of forced labour $r^{249}$ and, secondly, Article 25 of Convention No. 29 requires states to criminalise, prosecute, and

\footnotetext{
2431926 Slavery Convention, supra note 47, Art. 1(1). See also notes $47-50$ and accompanying lext, supra.

242 Lei no. 3353 de 1888 (known as the 'Lei Aurea').

2431956 Supplementary Slavery Convention, supra note 56, Art. 1(a).

24. 1 LO Convention No. 29, supra note 66, Art. 2(1).

245. Van der Mussele v. Belgium, supra note 40, para. 34.

246 See notes $10-13$ and accompanying text, supra.

247 See, e.g., LLO Convention No. 29, supta note 66, Art. 2(2)(d)-(e); ACHR, supra note 76, Art. 6(3)(c)-(d).

248 ILO Convention No. 29, supra note 66, Art. 1(2); 1926 Slavery Convention, supra note 47, Arts. 5-6.

243 lbid.
} 
punish the illegal exaction of forced labour. ${ }^{250}$ in all probability, a state that enacts legislation allowing the prosecution of forced-labour perpetrators may exercise its jurisdiction over both domestic and extraterritorial violations as long as, in the latter scenario, the offender and/or the victim are nationals of that state.

Nevertheless, it is questionable whether such a state may permissibly exercise its jurisdiction absent a nexus of territoriality or nationality, as would be the case with a Brazilian fazendeiro suspected of subjecting his own countrymen to forced labour within the borders of Brazil. The anti-forcedlabour norm's probable failure to rise to the level of jus cogens, ${ }^{251}$ along with the absence of an aut dedere aut judicare provision in any of the relevant conventions (obliging states either to prosecute or to extradite offenders found within their borders), make it less likely that the norm carries permissive universal jurisdiction. ${ }^{252}$ Indeed, neither of the LLO forced-labour conventions nor even the 1926 Slavery Convention rank among Professor Bassiouni's list of slavery-related instruments with provisions bestowing universal jurisdiction. ${ }^{253}$

Moreover, even if the anti-forced-labour norm does carry universal jurisdiction, states have overwhelmingly chosen not to exercise such jurisdiction-including over the core crimes of genocide, crimes against humanity, and war crimes ${ }^{2.54}$-and most have not enacted the necessary legislation to allow for its exercise. ${ }^{255}$ Prosecutions of foreigners for extraterritorial atrocities were almost unheard of until the 1990 s and have been quite rare since. ${ }^{256}$ Legislators and judges in Belgium and Spain have been the most pioneering in this regard, ${ }^{2.57}$ but even they have backed away in recent

250 HLO Convention No. 29, supra note 66, Art. 25.

253 See notes 102-103 and accompanying text, suprá.

${ }^{252}$ See Rather and Abrams, supra note 116, at 162. But see SS Lotus (France v. Turkey), 1927 PCII (Ser. A) No. 10 , at 18-19 (holding that a state may exercise its jurisdiction to prescribe anywhere in the world); Arrest Wartant of 11 April 2000 (DRC v. Belgium), Judgment of 14 February 2002, [2002] IC] Rep. 121 lhereinafter Arrest Warrant case], separate opinion of Judge Van den Wyngaert, para. 51.

253 M. C. Bassiouni, 'Universal Jurisdiction for International Crimes: Historical Perspectives and Contemporary Practice', (2001) 42 Virginia Journal of International Law 81, 112 [hereinafter Bassiouni 2001]. The list contains only two anti-siavery instruments, both dealing with the slave trade. See 1841 Treaty of London, supra note 46, Arts. VI, VII, X; 1890 Brussets General Act, supra note 46, Art. V.

254 Rather and Abrams, supra note 176 , at 185.

255 Bassiouni 2001 supra note 253 , at 105-106.

236 See, e.g., Affaire Barbie (French Court of Cassation, Chambre Criminelle, 20 December 1985), 1985 Bull. Crim., No. 407, 1053; Affaire Touvier (French Court of Cassation, Chambre Criminelie, 27 November 1992), 1992 Bull. Crim., No. 294, 1085; Public Prosecutor v. Menten (Dutch Hoge Raad 1981), 75 ILR 362 at 362-63; Regina v. Finta (Canadian Supreme Court 1994), 1 SCR 701, 814.

257 See Loi du 16 juin 1993 relative à la répression des infractions graves aux Conventions internationaux de Genève du 12 août 1949 et aux Protocols I et ll du 8 juin 1977, Additionnels à ces Conventions, Moniteur belge, 5 August 1993; Chilean Genocide case (Spanish Audiencia Nacional, 5 November 1998), reprinted in R. Brody and M. Ratner (eds.), The Pinochet Papers: The Case of Augusto Pinochet in Spain and Britain (2000). 
years ${ }^{258}$ in response to international criticism concerning the precarious legal basis of pure universal jurisdiction and the wisdom of basing prosecutions on it. ${ }^{259}$ Furthermore, the dearth of state practice in exercising universal jurisdiction over international crimes which have no nexus to the enforcing state militates strongly against the existence of such jurisdiction under customary international law, especially for a non jus cogens norm like that prohibiting forced labour. ${ }^{260}$

\subsubsection{Prosecution in the International Criminal Court}

Despite their ostensible role as the primary enforcers of international criminal law, states have failed overwhelmingly to play their part. To some extent in response to the woeful inadequacy of this envisaged indirectenforcement scheme, in recent years the international community has begun to resort to direct-enforcement schemes whereby an international court or tribunal may prosecute persons suspected of international crimes. ${ }^{26.1}$ The ICC is the only international court with global reach and, as Brazil ratified the Rome Statute on 14 June 2002, the Court could conceivably exercise jurisdiction over forced-labour fazendeiros for the thousands of violations that have occurred since 1 September of that year (see Table, infra). ${ }^{262}$ Because the atrocities at issue here are not committed in the context of armed conflict, the primary provision of the Rome Statute under which forced-labour perpetrators could be prosecuted is Article $7(1)(c)$, which sets forth the crime against humanity of enslavement. ${ }^{263}$

As discussed in Section 1, enslavement has appeared in every positive formulation of crimes against humanity since the Nuremberg Charter. ${ }^{264}$ Although few of the relevant instruments have provided a definition of the term or an enumeration of the activities it includes, Article $7(2)(\mathrm{c})$ of the Rome Statute defines enslavement for ICC purposes in language largely identical to that of the 1926 Slavery Convention: "Enslavement" means the exercise of

\footnotetext{
258 See Guatemala Genocide case, Decision No. 327/2003 (Supreme Court of Spain, 25 February 2003), available at (2003) 42 lLM 686. See also N. Roht-Arraiza, 'Universal Jurisdiction: Steps Forward, Steps Back', (2004) 17 LJH. 375, 385 386 (discussing 2002 Sharon case in the Appeals Court of Brussels).

259 See, e.g., H. Kissinger, 'The Pitfalls of Universal furisdiction', Foreign Affairs, July-August 2001, 86; Arrest Warrant case, supra note 252 , separate opinion of Judge Guillaume, paras. 7. 8 .

260 See Bassiouni 2001, supra note 253, at 148 .

261 See M. C. Bassiouni, 'Enforcing Human Rights Through International Criminal Law and Through an International Criminal Tribunal', in L. Henkin and 1. L. Hargtove (eds.), Human Rights: An Agenda for the Next Century (1994), 347 at 356-358 thereinafter Bassiouni 19941.

262 Rome Statute, supra note 31, Art. 126(1) (This Statute shall enter into force on the first day of the month after the 60th day following the date of the deposit of the 60 th instrument of ratification'). See also http:/ www.icc-cpi.int/asp/statesparties/coumtry\&id $=28$ html (listing dates of Brazil's signature and ratification of Rome Statute).

253 Rome Statute, supra note 37 , Art. $7(1)(\mathrm{c})$.

264 See notes $118-126$ and accompanying text, supra.
} 
any or all of the powers attaching to the right of ownership over a person and includes the exercise of such power in the course of trafficking in persons, in particular women and children. ${ }^{265}$ At the insistence of the United States and other delegations concerned that this definition was still excessively vague, ${ }^{266}$ the Elements of Crimes clarify that 'powers attaching to the right of ownership' could include 'purchasing, seling, lending or bartering such a person or persons, or ... imposing on them a similar deprivation of liberty. ${ }^{267}$

Upon initial examination, these qualifications appear to restrict the scope of enslavement to trafficking and traditional chattel slavery, thereby excluding an abundance of modern slavery-related activities such as forced labour; the phrase 'similar deprivation of liberty' could have left the definition open to the misinterpretation that enslavement requires some sort of commercial exchange. Many delegations at the drafting of the Elements opposed the illustrative list for precisely this reason, and after intense negotiations the delegates reached a compromise in the form of Canadian-proposed Footnote 11, providing that '[i]t is understood that such deprivation of liberty may, in some circumstances, include exacting forced labour or otherwise reducing a person to a servile status' ${ }^{268}$ The end result-a restrictive-sounding list qualified by an expansive footnote-prompted Darryl Robinson to refer to the ICC's enslavement provision as 'convoluted and inelegant'. ${ }^{269}$ To be sure, though the footnote makes it clear that forced labour can amount to enslavement in some circumstances', 270 This conclusion corresponds with that of Christopher Hall, who in his commentary to Article $7(1)(\mathrm{c})$ and $(2)(\mathrm{c})$ asserted as follows:

It is logical to assume that the drafters wished the Court to have jurisdiction over other slavery-like practices such as serfdom and debt bondage, as well as related practices, such as forced or compulsory labour, as crimes against humanity, given the history of the struggle over more than 200 years to abolish slavery, slavery-like practices, and forced labour.

\footnotetext{
265 Ibid, Art. $7(2)(\mathrm{c})$. Cf. 1926 Slavery Convention, supra note 47, Art. $1(1)$

260 Robinson, supra note 269 , at 85 .

267 ICC Elements of Crimes, supra note 125, Art. $7(1)(\mathrm{c})$, element 1.

263 lbid., Art. $7(1)$ (c), element 1 at $n .11$.

2ns D. Robinson, 'The Elements of Crimes Against Humanity', in R. S. Lee (ed.), The International Criminal Court: Elements of Crimes and Rules of Procedure and Evidence (2001), 85.C. K. Hall, 'Enstavement', in Otto Triffterer (ed.), Commentary on the Rome Statute of the International Criminat Court: Observers' Notes, Article by Article (1999), 132 at 134.

2\% This conclusion corresponds with that of Christopher Hall, who in his commentary to Article $7(1)(c)$ and (2)(c) asserted as follows:
} 
it fails to specify what these circumstances might include.

When faced with a concrete forced-labour case, the ICC will likely seek guidance in the case law of the ad hoc International Criminal Tribunals. As of October 2005 the chambers of the ICTY had had occasion to discuss the substance of the 'enslavement' provision in Article 5(c) of the ICTY Statute in only two cases: Kunarac in February $2001^{271}$ and June 2002,272 and Krnojelac in March $2002^{273}$ and September 2003. ${ }^{274}$

No chamber of the ICTR had yet discussed the substantive elements of 'enslavement' in Article 3(c) of that Tribunal's Statute as of October 2005.275

In the absence of statutory language indicating the exact meaning and scope of enslavement in Article 5(c), Trial Chamber II in Kunarac and again in Krnojelac analysed the existing authorities on slavery and related activities under international law-including the anti-slavery and anti-forced-labour conventions, human rights and humanitarian law instruments, the Nuremberg Judgment, and judgments rendered after the Second World War pursuant to Control Council Law No. $10^{276}$-in order to divine what it considered the customary international law definition of enslavement: 'the exercise of any or all of the powers attaching to the right of ownership over a person. ${ }^{277}$ As held by the Kunarac Trial Chamber, 'the actus reus of the violation is the exercise of any or all of the powers attaching to the right of ownership over a person', and 'the mens rea of the violation consists in the intentional exercise of such powers'. ${ }^{278}$ While the Trial Chamber obviously drew this language directly from the 1926 Slavery Convention, the Appeals Chamber emphasised that 'enslavement' under customary international law at the time of the events in the former Yugoslavia encompassed not only chattel slavery, but also the slave trade, servitude, forced labour, and any other contemporary form of slavery

271 Kunarac et at. Trial judgment, supra note 45 , paras, 515-543, 728-782.

272 Kunarac et al. Appeal Judgment, supra note 45, paras. 106-124.

273 Kinojelac Trial Judgment, supra note 45 , paras. 349-430.

274 Krnojelac. Appeal Judgment, supra note 45, paras. 189-207.

275 Indeed, besides Kunarac and Krnojelac, only one other judgment of either ad hoc Tribunal dedicates more than a passing reference to 'enslavement': the Simle Trial Judgment invoked paragraph 523 of the Kunarac Trial judgment and paragraph 356 of the Krnojelac Trial ludgment in support of its holding that both 'slavery' as a violation of the laws or customs of war (ICTY Statute Article 3) and 'enslavement' as a crime against humanity (ICTY Statute Article 5) 'require proof of the same elements! ! $_{\text {] }}$ and both terms can be used interchangeably.' Prosecutor v. Simiæe, Tadiæ, and Zariæ, Judgement, Case No. IT-95-9-T, 17 October 2003 , para. 85 and p. 28 n. 147 .

276 Kunarac et al. Trial Judgment, supra note 45, paras. 518-537; Krnojelac Trial judgment, supra note 45, paras. $352-353$

27\% Kunarac et al. Trial ludgment, supra note 45, para. 539. See also Kunarac et al. Appeal judgment, supra note 45 , ara. 116; Krnojelac Trial Judgment, supra note 45, para. 358.

278 Kunarac et al. Trial Judgment, supra note 45 , para. 540 . See also Kunarac ef al. Appeal fudgment, supra note 45 , paras. 116,122 . 
that involves 'some destruction of the [victim's] juridical personality'. ${ }^{279}$ In the Appeals Chamber's words, 'the destruction is greater in the case of "chattel slavery" but the difference is one of degree. ${ }^{280}$

The Trial Chamber convicted Dragoljub Kunarac of enslavement after finding that he had treated two girls that he had kept in an abandoned house for approximately six months 'as personal property': 'they had to do household chores and they had to obey all demands', including sexual demands. ${ }^{281}$ The Chamber additionally convicted Radomir Kovaè under Article $5(\mathrm{c})^{282}$ after finding that he had detained four women in an apartment, requiring them to 'take care of the household chores, the cooking and the cleaning', 283 and that he had 'sold' two of them for DM 500 to unidentified Montenegrin soldiers. ${ }^{284}$ The Chamber concluded that Kovaè had fulfilled the actus reus and mens rea of enslavement-that is, that he intentionally exercised powers attaching to the right of ownership over the women-in the following terms:

The Trial Chamber finds that Radomir Kovaè's conduct towards the two women was wanton in abusing and humiliating the four women and in exercising his de facto power of ownership as it pleased him. Kovaè disposed of them in the same manner. For all practical purposes, he possessed them, owned them and had complete control over their fate, and he treated them as his property. The Trial Chamber is also satisfied that Kovaè exercised the above powers over the girls intentionally. The Trial Chamber is satisfied that many of the acts caused serious humiliation, of which the accused was aware. ${ }^{285}$

\footnotetext{
279 Ibid., para. 117.

200 loid.

2B7 Kunarac et al. Trial Judgment, supra note 45, paras. $728-729,739,744-745$.

282 lbid., para. 782.

283 lbid, paras. 751, 780.

2 ib lbid., para. 775 .

20.5 Ibid., para. 781 .
} 
The Appeals Chamber upheld the Trial Chamber's convictions of Kunarac and Kovaè. ${ }^{286}$

As identified by the Trial Chamber in Kmojelac, and in line with both the text of ILO Convention No. $29^{287}$ and the European Court's holding in Van der Mussele $\checkmark$. Belgium, ${ }^{288}$ the touchstone for establishing that a given labour situation constituted enslavement is that the 'relevant persons had no real choice as to whether they would work. ${ }^{289}$ In this vein the Trial Chamber in Kunarac held that, in a situation of enslavement, '[t]he consent or free will of the victim is absent', 290 and this position was subsequently endorsed by the Appeals Chamber in Krnojelac: '[T] he "involuntariness" aspect [is] the definitional feature of forced or compulsory labour. ${ }^{291}$

Yet while it acknowledged that involuntariness is the central factor that turns permissible labour into enslavement, ${ }^{292}$ the Appeals Chamber stressed in both Kunarac and Krnojelac that the prosecution need not establish that the particular victim in question in fact lacked the consent to work. ${ }^{293}$ Consequently, the Krnojelac Appeals Chamber overuled the Trial Chamber's holding that the prosecution must prove, 'in every case', that 'the particular detainee had lost his choice to consent or to refuse the work he was doing. ${ }^{294}$ The Prosecutor had charged Milorad Krnojelac, the warden of a prison, with slavery-related activities in three separate counts of the indictment: Count 1 charged 'forced labour' as a predicate offence of persecution, a crime against humanity; ${ }^{295}$ Count 16 charged enslavement as a crime against humanity;, 296 and Count 18 charged 'slavery' as a violation of the laws or customs of war under Article $3 .^{297}$ The Trial Chamber acquitted Krnojelac on all three counts ${ }^{298}$ after finding that the prosecution had put forth insufficient evidence to prove that six of the eight victims in question individually lacked the consent to work. ${ }^{299}$ Moreover, while the Chamber found beyond a reasonable doubt that guards in Krnojelac's prison had indeed compelled two of the detainees to do mine-clearing work against the detainees'

\footnotetext{
286 Kunarac et al. Appeal Judgment, supra note 45 , para. 124.

${ }^{28 \%}$ H.O Convention No. 29, supra note 66, Ant. 2(1). See also notes 62, 89 and accompanying text, supra.

28. Van der Mussele v. Belgium, supra note 40, para. 34. See also Kunarac et al. Trial Judgment, supra note 45 , para. 535 (discussing Van der Mussele v. Betgium).

289 Kmojelac Trial Judgment, supra note 45 , para. 359.

2 Kumarac et al. Trial Judgment, supra note 45 , para. 542 .

291 Krnojelac Appeal Judgment, supra note 45, para. 191.

292 lbid.

293 Ibid.; Kunarac el al. Appeal Judgment, supra note 45, para. 120.

294 Kmojelac Trial Judgment, supra note 45, para. 380 (emphasis added).

295 Prosecutor v. Krnojelac, Third Amended Indictment, Case No. IT-97-25-1, 25 June 2001, para. 5.2(d) [hereinafter Kmojelac Indictment]. See also ICTY Statute, supra note 29, Art. 5(h).

296 Kmojelac Indictment, supra note 295, para. 5.46. See aiso ICTY Statute, supra note 29, Art. 5(c).

${ }^{297}$ Krnojelac Indictment, supra note 295, para. 5.46. See also ICTY Statute, supra note 29, Art. 3.

298 Kinojelac Trial ludgment, supra note 45 , paras, $425-430,471$.

${ }^{299}$ See ibid, paras. 386, 387, 388, 389, 390, 395.
} 
will, ${ }^{300}$ it nevertheless concluded that Krnojelac could not be held responsible as the guards' superior because the prosecution had failed to prove that he knew or should have known of this particular forced-labour situation, ${ }^{301}$

In overturning the Trial Chamber's acquittal of Krnojelac on Count 1, the Appeals Chamber held that, 'given the specific detention conditions of the non Serb detainees at [Krnojelac's prison] the KP Dom, a reasonable trier of fact should have arrived at the conclusion that the detainees' general situation negated any possibility of free consent. ${ }^{\prime 302}$ In other words, because '[t] the climate of fear at the prison made the expression of free consent impossible', any labour performed by any detainee was per se involuntary regardless of whether the detainee volunteered for the job, for example, to have more freedom or in the hope of obtaining additional food or cigarettes. ${ }^{30.3}$ The Appeals Chamber thus concluded that all eight of the detainees in question had indeed been 'forced to work' notwithstanding the prosecution's failure to prove that six of the individuals in fact lacked the consent to work. ${ }^{304}$ After finding that Krnojelac had participated in a joint criminal enterprise to persecute the eight detainees, the Chamber entered a conviction for forced labour as a form of persecution under Article $5(\mathrm{~h}) .^{305}$ Since the prosecution curiously did not appeal the Trial Chamber's acquittal of Krnojelac on Counts 16 (enslavement under Article 5(c)) and 18 (slavery under Article 3), the Appeals Chamber left these acquittals intact, ${ }^{306}$ and as a result only two persons-Kunarac and Kovaè--have thus far been convicted in the ad hoc Tribunals of enslavement as a crime against humanity.

While both the Trial and Appeals Chambers declined to enumerate exhaustively all of the contemporary forms of slavery that 'enslavement' comprehends, they provided the following list of 'indicia of enslavement ${ }^{307}$ to be weighed in each case to determine whether the accused exercised any or all of the powers attaching to the right of ownership over the victim: (1) the substantial lack of compensation; (2) the vulnerable position of the worker; (3) that the worker was detained; (4) the inhumane work conditions; ${ }^{308}(5)$ the duration of the relationship between the accused and the victim; ${ }^{309}(6)$ the exercise of control over the worker's movement and physical environment; (7) deception or false promises; (8) that measures were taken to prevent

\footnotetext{
300 Ibid., paras, $410-411$.

301 ibid., para. 429. See also ICTY Statute, supra note 29, Art. 7(3) (setting forth the doctrine of superior responsibility).

302 Kmojelac Appeal fudgment, supra note 45 , para. 194.

303 thid., paras. 194-795.

304 lbid., para. 196 .

3105 lbid, paras. 199-203, 206-207, pp. 113-114.

306 See ibid., paras. 189-190.

307 Kunarac et al. Appeal Judgment, supra note 45, para. 119.

30 Krnojelac Trial Judgment, supra note 45 , para. 373.

309 Kunarac et al. Appeal Judgment, supra note 45, para. 121.
} 
or deter escape, including psychological coercion and the threat of force; and (9) that the worker was subjected to cruel treatment. ${ }^{310}$ The acquisition or disposal of the worker for monetary or other compensation is decidedly not an element that the prosecution must establish to secure a conviction under Article 5(c) although, as the Kunarac Trial Chamber pointed out, "Idloing so ... is a prime example of the exercise of the right of ownership over someone..$^{311}$

Remarkably, nearly all of these indicia of enslavement characterise forced labour in the Amazonian context: the workers are lured to the fazenda under false pretences; they seldom manage to pay off their debt and thus never receive remuneration; their work conditions are dangerous and their housing conditions subhuman; and armed guards, psychological coercion, and the foreboding physical environment keep the workers from fleeing. Furthermore, since the individual victim's lack of consent need not be proven in order to establish the crime against humanity of enslavement-at least as construed in the case law of the ICTY-even the 40 percent of Brazilian peões previously freed by labour inspectors, and who have chosen to return to work at the same or another fazenda, can potentially qualify as victims of enslavement. ${ }^{312}$ Just as the subhuman conditions and climate of fear in Krnojelac's prison vitiated any consent to work that the detainees may have manifested, a sound argument could be made that labour performed on remote fazendas in hot, dangerous, and disease-ridden conditions, with no protective gear and under the constant vigilance of gunmen, is per se involuntary and thus unlawful.

In order for the prosecution to prevail on a charge of enslavement under the Rome Statute, it must also establish the general elements of crimes against humanity as set forth in the chapeau of Article 7(1): the enslavement must be 'committed as part of a widespread or systematic attack directed against any civilian population', and the individual perpetrator must have knowledge of such attack. ${ }^{313}$ Article $7(2)(a)$ and the Elements of Crimes clarify that the required 'attack' need not be military in character; ${ }^{314}$ to be sure, crimes against humanity under the Rome Statute, as under customary international law and in the ICTR Statute, need not have any connection to an armed conflict whatsoever, and need not even be carried out by means of violence. ${ }^{315}$ The attack must, however, be either 'widespread' (defined by the Akayesu Trial Chamber of the ICTR as 'massive, frequent, large-scale action' against 'a multiplicity of victims' ${ }^{\prime 316}$ ) or 'systematic' (defined as 'following a regular pattern on the basis of a common policy and involving substantial

\footnotetext{
330 Kunarac el al. Trial Judgment, supra note 45, paras. 542-543; Kunarac et al. Appeal Judgment, supra note 45, paras, $119-120$.

311 Kunarac et al, Trial Judgment, supra note 45 , para. 542 .

112 See notes 10-16, 145-148 and accomparying texi, supra.

313 Rome Statute, supra note 31, Art. $7(1)$.

1: bid., Art. 7(2)(a). See also ICC Elements of Crimes, supra note 125, Introduction to Art. 7 , element 3.

315 Robinson, supra note 269 , at $62,74$.

316 Prosecutor v. Akayesu, Judgement, Case No. ICTR-96-4-T, 2 September 1998, para. 580.
} 
public or private resources ${ }^{\prime 317}$ ), and it must involve the 'multiple commission' of offences 'pursuant to or in furtherance of a State or organizational policy. ${ }^{.318}$

As Robinson explains, 'multiple commission' of offences constitutes something less than 'widespread', and the requisite state or organisational policy need not be formalised, may come from either a state or a non-state organisation, and need not possess the 'very high degree of organization or orchestration' called for by the term 'systematic'. ${ }^{319}$

When attempting to establish these elements in respect of an accused forcedlabour fazendeiro, the prosecution could argue that the 'attack' on the civilian peões is widespread: even the estimates admitted to by the Brazilian government reveal that, despite recent progress in freeing workers, tens of thousands of civilians (including an estimated half of the entire adult male population of the state of Piauris ${ }^{320}$ ) are still subjected to forced labour on hundreds of fazendas all across the southern arc of the Amazon basin, and such has been the case for at least 30 years; this reality surely satisfies Article $7(2)(\mathrm{a})$ 's 'multiple commission' criterion as well. And although the government officially opposes forced labour, the pervasive fazendeiro networkincluding, among many others, complicit federal deputies and senators, governors, mayors, and state and federal police--evinces at the very least a de facto organisational policy to perpetuate the forced-labour status quo. Moreover, it should not be hard to prove in a given case that an accused forced-labour fazendeiro had knowledge of the attack: while few ordinary Brazilians in the densely populated central and southern regions are aware that forced labour exists in their country, individual fazendeiros certainly appreciate the critical role that such labour plays in the economy of the northern region and in the maintenance of their personal wealth..$^{321}$

A final but critically important hurdle that the prosecution must overcome before the ICC can declare a forced-labour case admissible will be to establish that the Brazilian state is either unwilling or unable-through the 'total or substantial collapse or unavailability of its national judicial system' - to undertake such prosecutions on its own. ${ }^{322}$ Recall that only two out of hundreds of fazendeiros have been convicted thus far of forced-labour crimes, and that neither of these men has spent a day in jail; this unhappy reality supplies strong circumstantial evidence of the unwillingness of state and federal prosecutors and judges to undertake such prosecutions or to allow them to go forward. In addition, the consistent stance of the federal trial and appellate courts of the northern region that the crime of reducing someone to a condition analogous to slavery does not fall under federal jurisdiction, as well as the atmosphere of coercion and assassinations that plagues prosecutors and judges, ${ }^{32.3}$ supports

\footnotetext{
317 lbid.

318 Rome Statute, supra note 31, Art. $7(2)(a)$.

319 See D. Robinson, 'Defining "Crimes Against Humanity" at the Rome Conference', (1999) 93 AJlL 43, 48 m. 51.

320 Rezende, supra note 10 , at 112.

321 See Bales, supra note 7 , at $125,147,236$. See also notes $21-22$ and accompanying text, supra.

322 See Rome Statute, supra note 31, Arts. 17, 15(3), 53(1).

323 See notes $151-156,191-205$ and accompanying text, supra.
} 
the proposition that the national judicial system of the portion of Brazil where forced labour occurs has been rendered substantially unavailable. ${ }^{324}$

\section{Conclusion: International criminal law as the ultima ratio modality of human rights protection}

Despite states' almost universal condemnation of slavery, the slave trade, slavery-like practices, and forced labour, such activities are decidedly not yet relics of the past. The very real depredations suffered by rural workers in the north of Brazil provide just one of many examples of how the classic modality of human rights protection-state civil responsibility - has thus far failed to deal satisfactorily with the world's modern manifestations of slavery.

Notwithstanding the existence of positive obligations on states to ensure to all within their jurisdiction the effective enjoyment of certain human rights, ${ }^{325}$ human rights law quite often falls short in respect of violations perpetrated by private individuals-especially when carried out in remote areas outside the reach of the state apparatus - and in such cases international criminal law can serve a crucial gap-filling function. Professor Bassiouni has characterised resort to criminal proscription as the 'ultima ratio' modality of human rights protection, resorted to when other modalities of protection prove inadequate to remedy or provide redress for a given class or circumstance of offences. ${ }^{326}$ International criminalisation is thus situated at the far end of a continuum consisting of five stages: enunciation (the emergence of shared values); declaration (the identification of specific rights); prescription (the enshrinement of normative proscriptions in international instruments); enforcement; and, ultimately, criminalisation if and when the modalities of protection of the other stages fall short. Because governments have predictably been loath to censure themselves and their own agents and organs, Bassiouni blames the momentous deficiencies of the state-responsibility modality on the fact that the majority of human rights abuses in the world are perpetrated by public or quasi public officials acting under colour of state authority..$^{327}$

Bassiouni's human rights continuum provides a useful tool for analysing the effectiveness of international law's enforcement modalities in respect of forced labour in Brazil. The norms outlawing the slave trade and slavery were among the very first to emerge and achieve positive formulation in what today can be thought of as prototypical human rights treaties, followed in short order by prohibitions on related institutions such as forced labour. These various instruments enjoy wide ratification and form part of customary international law, binding all states under menace of civil liability and opprobrium by the international community. Even after noteworthy efforts by the Brazilian government under Presidents Cardoso

\footnotetext{
324 See Rome Statute, supra note 31, Art. 17(3). See also ICC Office of the Prosecutor (ed.), Informal Expert Paper: The Principle of Complementarity in Practice (2003), paras. 44...50 (on file with author).

32.5 See text accompanying notes 214-237, supra.

326 Bassiouni 1982, supra note 212, at 193; Bassiouni 1994, supra note 261, at 354 .

327 See Bassiouni 1982, supra note 212, at 193-196. See also Bassiouni 1994, supra note 261, at 354.
} 
and Lula to establish mechanisms to bring about the eradication of Amazonian forced labour, Brazil faces civil liability for its ongoing failure to prevent a whole host of violations of the anti-forced-labour norm. This glaring insufficiency of the state-responsibility modality of enforcement militates strongly in favour of international criminal accountability for fazendeiros and their henchmen.

In order for Bassiouni's theory to accurately explain the Brazilian scenario, however, a slight modification would appear necessary. As discussed in Sections 2 and 3 , the malfunction of the state-responsibility scheme in the case of Brazilian forced labour has not come about because of the federal government's resistance to sanctioning its own commission of forced labour, but because of its lack of effective control over the activities of private individuals and those under such individuals' influence. The drafters of the Rome Statute seem to have had both scenarios in mind when devising the alternative admissibility criteria of 'unwillingness' and 'inability': ${ }^{328}$ cases declared admissible due to the state's unwillingness to prosecute will typically involve accused who committed their alleged crimes under the colour of state authority, and those declared admissible because of inability will quite often involve private individuals-such as terrorists and traffickers in women and children-over whom the state in question has little or no control.

Since the inception of the International Criminal Court, the Prosecutor has seriously considered or begun investigations in just five situations - in the Democratic Republic of the Congo, Uganda, Ivory Coast, the Central African Republic, and Sudan-all in Africa and all involving societies engaged in armed conflict. Nevertheless, although the crimes-against-humanity formulations in the Nuremberg and Tokyo Charters and the ICTY Statute call for some sort of linkage to an armed conflict, ${ }^{329}$ none of the other relevant instruments-including the ICTR and Rome Statutes-contains such a requirement, ${ }^{330}$ nor does customary international law. ${ }^{331}$ The ICC has been in existence for more than three years and the Prosecutor, struggling with investigations in adverse conditions in Uganda and the Congo, has only recently issued his first five indictments. ${ }^{332}$ For fear that states' enthusiasm for the Court may wane and funds and support may be withdrawn, it would appear incumbent upon the Prosecutor to consider the great multitude of atrocities being committed on the territory of states parties that, while perhaps less sensational than the armed-conflict crimes in Sudan or Uganda, are still highly odious and should prove much more susceptible to investigation and the rapid construction of a prosecution case. The enslavement of thousands of workers on hundreds of fazendas across the Brazilian Amazon would seem to be replete with concrete cases that could serve to get the 1CC off the ground.

\footnotetext{
328 Rome Statule, supra note 31, Art. 17.

329 Nuremberg Charter, supra note 41, Art. 6(c); Tokyo Charter, supła note 42, Art. 5(c); ICTY Statute, supra note 29, Art. 5.

330 See ICTR Statute, supra note 30, Art. 3; Rome Statute, supra note 31, Art. 7(1).

331 See Prosecutor $v$. Tadia, Decision on the Defence Motion for fnterlocutory Appeal on Jurisdiction, Case No. IT-94-1-AR72, 2 October 1995, para. 141.

332 'Catching a Ugandan Monster', Economist, 22 October 2005, 46 (stating that the ICC has issued arrest warrants for Joseph Kony and four other Lord's Resistance Army leaders).
} 